\title{
ZMĚNY SÍDLIŠTNIICH STRUKTUR V OKOLÍ RONOVA NAD DOUBRAVOU
}

\author{
ONDŘEJ MALINA - JAN MUSIL - PETR NETOLICKÝ
}

\begin{abstract}
Abstrakt: V západním cípu okresu Chrudim (dřive historická součást Čáslavska) vokoli města Ronova nad Doubravou se nalézaji relikty několika zaniklých vsí, panských sídel s přidruženým hospodářským zázemím včetně dvorů, mlýnů a několika rybníků. V průběhu středověku se jednalo o hraniční zónu mezi lichtenburským panstvím a državami vilémovského kláštera (hranici tvořila samotná řeka Doubrava). I na tomto územi se ale nalézaly samostatné državy. Krajina v okoli města prošla několika razantními transformacemi, které ovlivnily strukturu zdejšího osídlení. Jednou z nich bylo založení města. Přrispěvek se zaměruje na komparaci dostupných pisemných a archeologických pramenů ve vymezeném mikroregionu bezprostředního okoli Ronova nad Doubravou.
\end{abstract}

Klíčová slova: transformace osidlení - analytický povrchový sběr - zaniklá středověká ves - samostatně stojici kostel.

\section{Changes in settlement structures in the vicinity of Ronov nad Doubravou}

Abstract: Remains of several deserted villages, feudal estates with affiliated hinterland facilities including homesteads, mills and several fishponds are located in the western tip of the Chrudim district (formerly a part of the Ćáslav region), near the town of Ronov nad Doubravou. In the Middle Ages, this was a border area between the Lichtenburk demesne and the holdings of the Vilémov monastery (the border was the river Doubrava). However, the region also included further independent holdings. The landscape around the town underwent several radical transformations in the past which influenced the structure of the local settlement. One of them was the establishment of the town. This contribution centres on the comparison of the available written and archaeological sources in the observed microregion in the immediate surroundings of Ronov nad Doubravou.

Key words: settlement transformation - analytical surface collection - deserted medieval village - free-standing church.

\section{1 Úvod}

V souvislosti s plněním dlouhodobého vědeckovýzkumného úkolu zaměřeného na poznání osídlení od pravěku po raný novověk na území okresu Chrudim se od roku 2008 výzkumu nemovitých kulturních památek systematicky věnuje Regionální muzeum v Chrudimi ve spolupráci s Katedrou archeologie Západočeské univerzity v Plzni. Navazujeme tím na poznatky získané především metodou povrchových sběrů prováděných v severní nížinaté části Chrudimska (Frolík-Sigl 1995) a v neposlední řadě také Ronovska (Malina 2011, 111-114; 2012, obr. 4). Souběžně probíhá výzkum zalesněných oblastí Železných hor a Žd’árských vrchů (srov. Musil 2007; 2011; 2011a; Musil-Netolický 2012; 2013; 2014; 2014a; 2014b; 2014c; 2015; 2015a; 2016; 2016a; 2017; 2018). Předložený př́spěvek si klade za cíl zkombinovat data získaná analytickými povrchovými sběry s výsledky geodeticko-topografického průzkumu antropogenního reliéfu v zázemí dnešního Ronova nad Doubravou (okr. Chrudim, Pardubický kraj), který má značný význam pro pochopení změn sídlištních struktur ve stř̌edověkém období (obr. 1).

\section{Geografické a historické vymezení zkoumaného území}

Okolí města Ronova nad Doubravou společně s majestátným hradem Lichnicí (obr. 1:1) náleželo do někdejšího historického Čáslavska. V současnosti administrativně náleží okresu Chrudim ležícím v Pardubickém kraji. Relativně otevřená krajina Polabí se zde mírně vlní a postupně přechází v masiv Železných hor, které ve středověku tvořily přirozenou bariéru. Důležitou spojnici v oblasti prredstavovala řeka Doubrava, podél níž probíhala tzv. Libická stezka. V okolí města se nalézají dva samostatně stojící románské kostely, u nichž stávaly - při někdejším brodu přes řeku Doubravu - středověké vsi Protivany/Protivenice (obr. 1:4; 2) a Stusyně (obr. 1:3; 2). Obě tyto zaniklé vesnice předcházely vzniku Ronova nad Doubravou (obr. 1:2), který nechal 


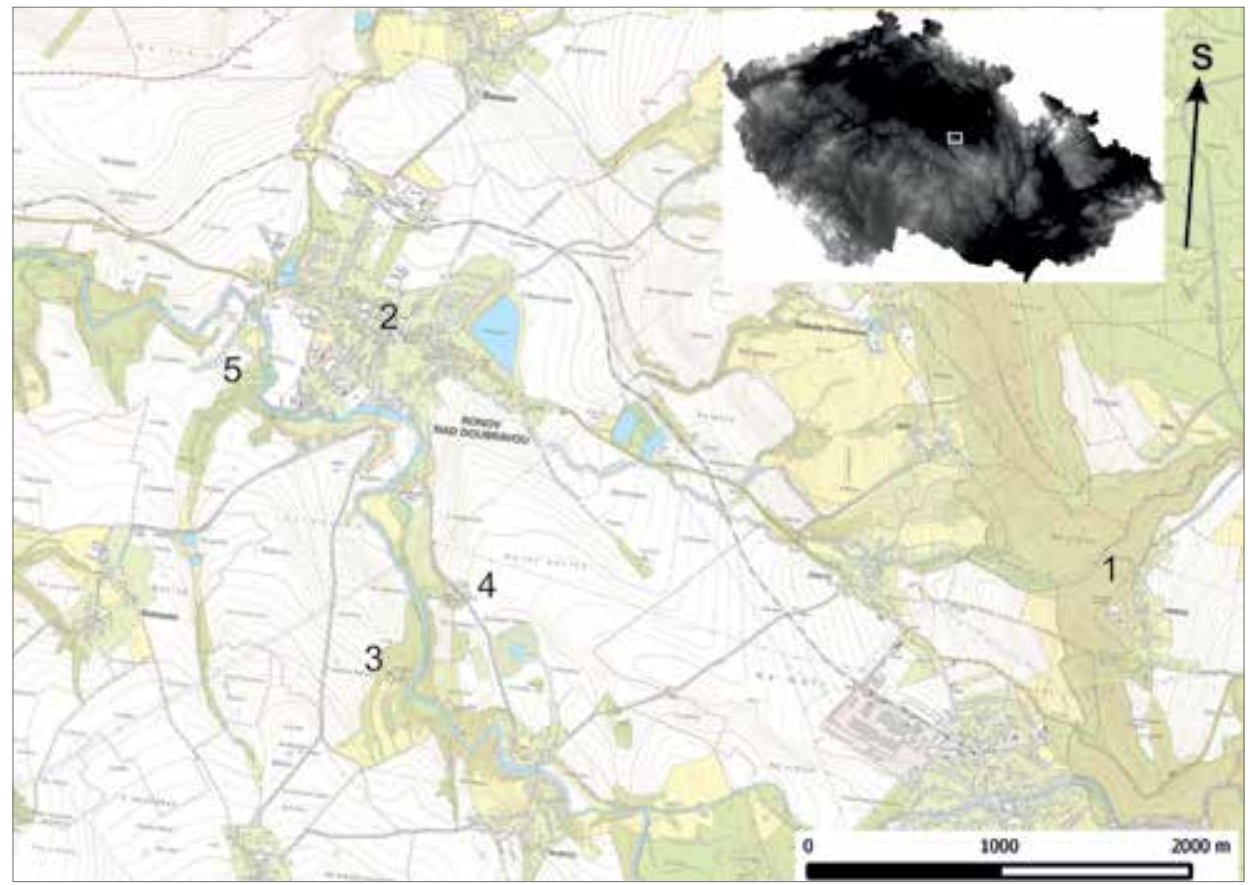

Obr. 1. Lokality zmiňované v textu. 1 - hrad Lichnice (k. ú. Podhradí v Železných horách); 2 - Ronov nad Doubravou; 3 - ZSV Stusyně (k. ú. Ronov nad Doubravou); 4 - ZSV Protivany/Protivenice (k. ú. Ronov nad Doubravou); 5 - ZSV a tvrz Suchotlesky (k. ú. Ronov nad Doubravou). Zdroj podkladové mapy ČÚZK, Základní mapa ČR 1 : 10000. Vytvořeno v programu QGIS.

Abb. 1. Im Text erwähnte Fundstellen. 1 - Burg Lichnice (Katastergebiet Podhradí im Eisengebirge); 2 - Ronov an der Doubrava; 3 - Mittelalterliche Dorfwüstung (Katastergebiet Ronov an der Doubrava); 4 - mittelalterliche Dorfwüstung Protivany/Protivenice (Katastergebiet Ronov an der Doubrava); 5 - mittelalterliche Dorfwüstung und Festung Suchotlesky (Katastergebiet Ronov an der Doubrava). Quelle Grundkarten des Tschechischen Amtes für Landesvermessung und Kataster, Grundkarte der Tschechischen Republik 1 : 10000 . Erstellt mit der Software QGIS.

založit Oldřich z Lichtenburku v roce 1307 (RBM IV, 823 č. 2124). Právě u osady Protivany s kostelem sv. Kříže se předpokládá existence někdejšího trhového místa. Trh byl pak společně s centrem farní správy přesunut do nově založeného městečka (Šimák 1938, 1221-1222). Obě osady ztrácely postupně na významu, ale definitivní tečku za jejich existencí učinily až události třicetileté války. Počátkům města Ronova nad Doubravou a jeho vztahu k zaniklým Protivanům/ Protivenicím (Profous 1951, 493; Roubík 1959, 107; Svoboda-Šmilauer 1960, 354; Smetánka 1987, 239; Pehal 2003, 3-17) a Stusyni (Profous-Svoboda 1957, 226; Roubík 1959, 108; Svoboda-Šmilauer 1960, 354; Smetánka-Škabrada 1975, 262-266; 1977, 105-112; Smetánka 1987, 242) byla v minulosti věnována značná pozornost, zejména co se týče transformace středověké sídelní sítě (nejnověji Malina 2011; 2012).

V jihozápadní části katastru města Ronova nad Doubravou se nalézají poněkud opomenuté relikty další zaniklé střredověké vsi Suchotlesky (obr. 1:5). Komplex sestává z vlastní zaniklé vsi, panského sídla (tvrze) s přidruženým hospodářským zázemím v podobě dvora a mlýna s minimálně třemi rybníky (Musil-Netolický 2018). Vesnice je známa zejména ze starší regionální literatury (Čermák 1882-1884, 238; Culek 1958, 47-52) a přehledových soupisových prací (Birnbaumová-Jansová 1929, 327-329; Roubík 1959, 108; Profous-Svoboda 1957, 234).

Jak vyplývá z předloženého výčtu, na katastru současného města Ronova nad Doubravou se ve středověku nalézaly původně tři osady - Suchotlesky, Stusyně a Protivany. U dvou 
posledně zmiňovaných se dochovaly dodnes stojící románské kostely. Toto území tak představuje významný sídelně geografický palimpsest, který již po několik desetiletí přitahuje pozornost odborné veřejnosti.

\section{Charakteristika př́rodního prostředí}

Skalní podklad tvoří sedimenty české křídové pánve a Dlouhé meze, konkrétně slínovce spodního až středního turonu. V některých místech jsou tyto sedimenty denundovány a na povrch vystupují krystalické horniny Čáslavské kotliny a železnohorského proterozoika. V údolí řeky Doubravy nalezneme i vyvřelinové formace tvořené gabrem. Levobřeží Doubravy je pokryto souvislým pásem spraší a sprašových hlín. Průměrná nadmořská výška činí $280 \mathrm{~m}$ n.m. $Z$ vegetačního hlediska se zde jako původní rostlinný pokryv předpokládají dubohabrové háje, místy acidofilní doubravy. Kolem vodotečí se pak nalézají luhy a olšiny. Z klimatického hlediska se území nalézá v oblasti mírně vlhké. $Z$ pedologického hlediska se na polygenetických hlínách s eolickou a štěrkovitou příměsí vytvořil pseudoglej typický (kambický), který místy vytváří asociace s kambizeměmi. V oblasti mezi Ronovem nad Doubravou a Mokrou Lhotou se nalézají ostrůvky pararendziny typické a kambizemní na slínech, slínových jílech a svahovinách opuk (Faltysová-Bárta, edd., 2002, 40, 43, 76, 94).

\section{Stručné dějiny oblasti}

Mikroregion s ústředím Ronova nad Doubravou byl osídlen již v mladší době hradištní, o čemž svědčí i solitérní nálezy uváděné starší regionální literaturou (napřr. Birnbaumová-Jansová 1929, 28-31). Stranou našeho zájmu ponechejme období pravěké, které je rovněž doloženo nálezy pokrývajícími období neolitu až doby laténské (srov. Birnbaumová-Jansová 1929, 289-290). Podoubravím procházela důležitá komunikace, nazývaná později Libická stezka. V okolí Ronova nad Doubravou se setkáváme s nejstaršími stojícími stavbami registrovanými v rámci okresu Chrudim (kostel sv. Martina a sv. Kř́že na katastru obce, kostel sv. Máŕí Magdaleny v Pařížově). Kostel v Běstvině u Pařížova je zmiňován v popisu zázraku o uzdravení ženy v roce 1137 u Kanovníka vyšehradského (FRB II, 225-227). Významným kolonizačním činitelem v oblasti byl benediktinský klášter v nedalekém Vilémově, jehož pozemková doména dosahovala až do nitra Železných hor. Klášter zanikl v roce 1421 a jeho majetek byl rozchvácen místní šlechtou. Od 13. století můžeme počítat s vlivem mocných Ronovců, reprezentovaných zejména Lichtenburky sídlícími na nedalekém hradě Lichnice.

\subsection{ZSV Stusyně}

Relikty zaniklé středověké vsi Stusyně s románským kostelem sv. Martina (obr. 1:3; obr. 3 a 4) se rozkládají na levém břehu řeky Doubravy na jižním okraji katastru Ronova nad Doubravou v sousedství vsi Mladotice (Roubík 1959, 108; Svoboda-Šmilauer 1960, 354). Vlastní kostel leží uprostřed dodnes užívaného hřbitova, který je přístupný zpevněnou místní komunikací od nedalekých Mladotic. Středověké sídliště související bezprostředně s kostelem bylo umístěno na poměrně rozlehlém ostrohu, který je na severozápadní a západní straně vymezen roklí a na východní straně řekou Doubravou. V rokli na západní straně se nalézala původně menší vodoteč. Prostor na jihovýchodní straně uzavírá ještě jedna menší rokle. Břeh řeky Doubravy je výrazně skalnatý a těžko prrístupný. Samotný kostel se hřbitovem se nalézá v jihozápadní části takto vymezeného prostoru. Na základě povrchových průzkumů prováděných v letech 1974-1977 Zdeňkem Smetánkou byly stopy osídlení zjištěny v těsném sousedství hřbitova na ppč. 1819 a západně, jihozápadně a jižně od kostela. Osídlení bylo registrováno rovněž i na ppč. 1757 a 1823 nepravidelně při hraně strže a severozápadně od kostela. Osada se tedy nalézala na mírně zvlněné plošině (Smetánka 1977). 


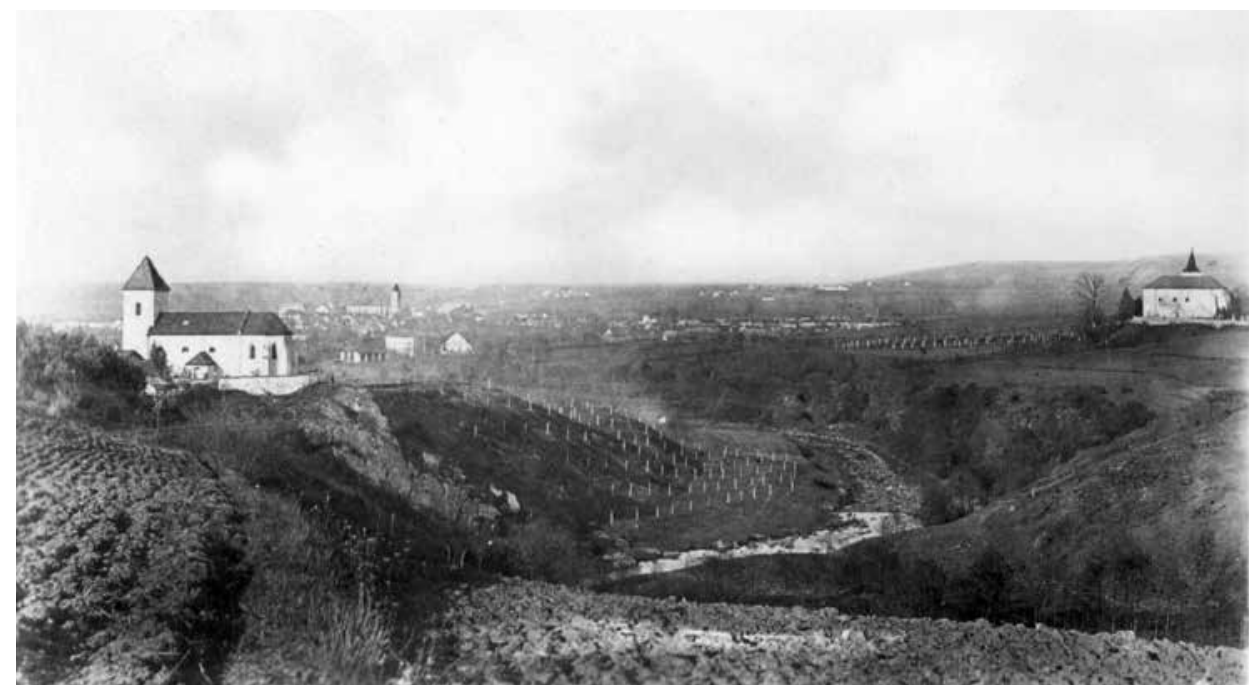

Obr. 2. Historický snímek údolí řeky Doubravy z let 1939-1944 ukazující situaci před zalesněním. ZSV Stusyně (k. ú. Ronov nad Doubravou) s kostelem sv. Martina (vlevo) a ZSV Protivany (k. ú. Ronov nad Doubravou) s kostelem sv. Kř́ǐze (vpravo). Uprostřed je patrný brod přes řeku. Zdroj Sbírka P. Fiedlera.

Abb. 2. Historische Aufnahme des Flusstals der Doubrava aus den Jahren 1939-1944 mit Situation vor der Aufforstung. Mittelalterliche Dorfwüstung Stusyně (Katastergebiet Ronov an der Doubrava) mit St. Martinskirche (links) und mittelalterlicher Dorfwüstung Protivany (Katastergebiet Ronov an der Doubrava) mit Heilig-Kreuz-Kirche (rechts). In der Mitte ist die Furt über den Fluss zu sehen. Quelle Sammlung P. Fiedler.

Do odborného povědomí se lokalita dostala na sklonku 19. století. Kliment Čermák zmiňuje od kostela sv. Martina nález velké bronzové záušnice (Birnbaumová-Jansová 1929, 325). Zaniklé vsi a kostelu se věnoval již zmiňovaný Zdeněk Smetánka společně s Jiřím Škabradou (Smetánka-Škabrada 1975, 262-266; 1977, 105-112; Smetánka 1987, 242).

Písemné prameny počátky vsi a kostela příliš neosvětlují. První písemná zmínka o kostele pochází až z roku 1352, známe i sled farářů z let 1374-1415 (Kurka 1914, 159; LE V, 755 č. 1041; LC III, 16). Kostelní podací měl ke kostelu sv. Martina vilémovský klášter, k jehož pozemkové doméně Stusyně patřila. Po zániku kláštera se písemné prameny o vsi na více než sto let odmlčují. Na základě analýzy zlomků keramiky získaných v letech 1974-1977 je možno soudit, že ves existovala ještě v první polovině 16. století (srov. Smetánka 1977, 5). Při majetkové transakci roku 1578 je připomínán pouze mlýn „pod Štusinou slove Podskalni“" (Profous-Svoboda 1957, 226). Zmínky o podacím ke kostelu ve Stusyni nalezneme i při majetkových transakcích z let 1588 a 1615 (Profous-Svoboda 1957, 226). Ćást plužiny zaniklé vsi byla v 17. století přičleněna ke dvoru v nedalekých Suchotleskách (Zahradníková-Šreinová 1999, 406, 419).

\subsection{Protivany}

Relikty zaniklé vsi Protivany (obr. 1:4) se nalézají na výrazné terase na pravobřeží řeky Doubravy, v jihojihovýchodním cípu katastrálního území Ronov nad Doubravou. Nejmarkantnějším pozůstatkem vsi je gotický, v jádru románský kostel sv. Křŕže, který se nalézal nad někdejší vsí při horní hraně této terasy. Severozápadně od kostela se rozkládá široká úžlabina svažující se k někdejšímu brodu přes řeku Doubravu. První zprávu o existenci archeologických situací ztotožnitelnou s pozůstatky vsi publikoval Kliment Čermák $(1885,7-8 ; 1893,819)$. Osada byla zmiňována i ve starší regionální historické a místopisné literatuře (Birnbaumová-Jansová 1929, 290-296; Profous 1951, 493; Roubík 1959, 107; Sedláček 1909, 44; Svoboda-Šmilauer 
1960, 354). Intenzivní průzkum oblasti prováděl již zmiňovaný Zdeněk Smetánka. Výsledky průzkumu jsou jen informativně zmíněny v populárně naučné publikaci věnované archeologii středověku (Smetánka 1987, 239). Doposud posledním počinem k poznání materiální kultury vsi a jejích počátků je studie Zdeňka Pehala (2003) věnovaná rozboru nálezů z jím prováděných povrchových sběrů. Jak se zdá, ves se rozkládala naproti původnímu vstupu do kostela, na oválné ploše o rozměrech $150 \times 90$ m na terase řeky Doubravy. Severně od kostela se nalézá úsek úvozové cesty směřující k brodu přes řeku (srov. Smetánka 1987, 239-240).

První výslovná písemná zmínka pochází, podobně jako $\mathrm{v}$ předešlém př́ípadě, až z roku 1352 (Kurka 1914, 159). Nicméně můžeme ji posunout ještě k roku 1307, kdy je v zakládací listině města Ronova výslovně zmiňována zdejší fara (srov. RBM IV, 823 č. 2124). Ústředním bodem osídlení byl v jádru románský kostel sv. Kříže (k datování a stavebně historickému vývoji kostela Smetánka-Škabrada 1977, 106-107), který sloužil jako farní i pro nedaleké městečko. Podací právo ke kostelu měl pán lichtenburského panství, známe jménem zdejší faráře z let 1366, 1371, 1374, 1403 a 1413 (Kurka 1914, 159). Z povrchových průzkumů pochází kolekce raně a vrcholně středověké keramiky (Pehal 2003, 3-17). Společně se vsí Stusyně byly položeny poblíž komunikace a brodu přes Doubravu (srov. obr. 2). V roce 1597 je ves uváděna jako pustá. Podle Františka Roubíka $(1959,107)$ zanikla během tažení Jana Žižky do východních Čech v roce 1421.

\subsection{Suchotlesky}

V jihozápadní části katastru města Ronova nad Doubravou se nalézají poněkud opomenuté relikty zaniklé středověké vsi Suchotlesky. Komplex sestává z vlastní zaniklé vsi, panského sídla (tvrze) s přidruženým hospodářským zázemím v podobě dvora a mlýna s minimálně třemi rybníky (Musil-Netolický 2018). Počátky tvrze a vsi Suchotlesky u Ronova nad Doubravou dostupné písemné prameny př́liš neosvětlují. První spolehlivé zmínky pocházejí až z 16. století. Nutno předeslat, že dispozice zdejší tvrze poukazuje na středověké založení. Navíc musíme předpokládat poměrně značnou transformaci zdejší sídelní sítě v rámci založení města Ronova nad Doubravou v roce 1307. Nedomníváme se, že by ke vzniku vsi mohlo dojít až po tomto roce. Podle Augusta Sedláčka $(1909,848)$ náležely původně k majetku vilémovského kláštera, poté $\mathrm{k}$ lichtenburskému panství (k rekonstrukci klášterních držav srov. zejm. Somer-Šrámek 2010, 16-38, Mapa 1; ve shodě s nimi i Musil-Netolický 2018). Další nepřímý důkaz někdejší držby klášterem bychom mohli spatřovat v držbě Trčků z Lípy. Statky vilémovského kláštera zničeného v roce 1421 při husitském tažení do východních Čech připadly dílem Janu Hertvíkovi z Rušinova, dílem Trčkům z Lípy (srov. Somer-Šrámek 2010, 41). Suchotlesky Trčkům náležely výslovně do roku 1557. Vlastní lichtenburské panství bylo prodáno Vilémem Trčkem z Lípy roku 1555 poručníkům Albrechta a Václava Robmhápa ze Suché. Albrecht Robmháp se po dosažení zletilosti zmíněného roku 1555 chopil správy panství a k němu dokoupil roku 1557 od Viléma Trčky z Lípy vsi Kněžice, Biskupice, Suchotlesky a Mladotice, tj. evidentně díl, který byl k lichtenburskému panství připojen dodatečně. Suchotlesky roku 1582 sestávaly z usedlosti Jana Kmoška a Šimka Havlova, připojen k nim byl i grunt Ad. Matějíčka ve vsi Biskupicích. Ten roku 1614 vyhořel, načež se Matějíček společně se svou manželkou bez výhostu vytratil. Pozemky tohoto hospodářství byly připojeny k hospodářskému dvoru v Suchotleskách (Čermák 1882-1884, 238). Roku 1588 dal Albrecht Robmháp své čtvrté manželce Anně Salavovně z Lípy věnem vsi Kněžice, Biskupice, Suchotlesky a Mladotice; v jejím držení zůstaly vsi do konce jejího života. Potvrzuje to i Albrechtova závět' z roku 1592. Po smrti Anny mělo její někdejší věno připadnout Janovi, Albrechtovu synovi, který ovšem zemřel již roku 1595. Za jeho nezletilé syny Albrechta staršího a Václava se do roku 1614 o Suchotlesky staral Zikmund Robmháp (Sedláček 1900, 46). Roku 1615 se bratři rozdělili, Albrecht starší si ponechal Suchotlesky, zatímco Václav Moravany. Ačkoliv byl Albrecht starší nekatolík, při stavovském povstání na rozdíl od svých př́ibuzných zachoval věrnost císaři, proto byl roku 1622 zproštěn obžaloby. V soupisu odvodů kontribuce pro Čáslavský kraj v roce 1622 je uvedeno, že Albrecht starší Robmháp ze Suché a na Suchotleskách odvedl kontribuci za 15 osob (Čermák 1874-1877, 324). Albrecht starší zůstal své víře věrný, 
a proto po obnoveném zřízení zemském roku 1627 emigroval. Suchotlesky koupil Jan Rudolf Trčka z Lípy, který je držel až do svého osudového pádu roku 1634 (Sedláček 1900, 45-46). Suchotlesky se tak v letech 1628-1636 staly součástí ledečského panství (srov. Sedláček 1900, $89,114)$. V roce 1636 byl majetek Jana Rudolfa Trčky z Lípy zkonfiskován. V soupisu je uváděna tvrz Suchotlesky s poplužním dvorem s 4,5 lány polí, 12 koňmi, 37 kusy hovězího dobytka a 180 ovcemi (Bílek 1883, 688). Jedná se o poslední písemnou zmínku o existenci tvrze tohoto jména, sama ves zanikla $\mathrm{v}$ průběhu třicetileté války. Suchotlesky spolu s Bohdančí daroval císař roku 1636 Anně Kylmanové z Kylmanseku a ta je roku 1638 prodala Františkovi Chiesa na Ronově (Sedláček 1900, 46). Dle soupisu poddaných podle víry z roku 1651 víme, že ze zdejšího sídlištního komplexu existoval už pouze hospodářský dvůr. K tomuto dvoru náležely nejen plužiny někdejší vsi Suchotlesky, ale byla k němu připojena i část plužiny zaniklé vsi Stusyně (Zahradníková-Šreinová 1999, 406, 419). Poslední zmínka o existenci už jen samostatného dvora pochází z roku 1727 (Čermák 1882-1884, 238).

Od počátku 17. století sledujeme postupnou ztrátu významu danou polohou v blízkosti městečka Ronova nad Doubravou. Již v roce 1582 z vesnice zbývaly pouhé dvě usedlosti. $\mathrm{K}$ vrchnostenskému dvoru byly připojovány pozemky zpustlých usedlostí z blízkého okolí. Definitivní tečkou byly události třicetileté války.

\subsection{Ronov nad Doubravou}

V souvislosti s upevňováním lichtenburské državy došlo k založení hradu Lichnice, pod nímž vznikla osada Podhradí. Tato vesnice, později městečko, měla patrně hospodářsky saturovat potřeby hradu (Šimák 1938, 1221), protože její odlehlá a špatně dostupná poloha mimo trasu Libické stezky znemožňovala jinou úlohu. Novým potřebám patrně nevyhovovala ani ves Protivany s kostelem sv. Kř́žze, a proto bylo roku 1307 založeno Oldřichem z Lichtenburka město Ronov nad Doubravou. Z urbanistického hlediska představovalo jádro města zhruba čtvercové náměstí obklopené jednotlivými domy měštanů. Město při ohbí na pravém břehu řeky Doubravy bylo založeno na ,zelené louce“ o rozloze 39 lánů, bylo vybaveno krčmou, masným a chlebným krámem, později i lázní (RBM IV, 823 č. 2124). Nejlépe se Oldřichova motivace odráží v názvu města, užívaného až do 19. století, Markt Ronov, tj. Trhový Ronov. Celý zakladatelský akt byl tedy motivován translací trhového místa. Po založení náleželo město pod farní správu u kostela sv. Kř́žze v Protivanech, kaple ve městě je výslovně zmíněna až roku 1334 v souvislosti s privilegiem Jana Lucemburského (Kurka 1914, 159), nicméně i ta byla podřízena farnosti u sv. Křŕže.

Jak bylo řečeno výše, Ronov se stal součástí lichtenburského panství. V důsledku zadlužení Lichtenburkové panství prodali v první polovině 14. století králi a po husitských válkách se dostalo do držení Trčků z Lípy, kteří panství v roce 1555 prodali. Majiteli panství se stali Robmhápové ze Suché, kteří v místě vybudovali tvrz. K roku 1564 se v Ronově připomíná 161 osedlých (srov. Sedláček 1900, 44, pozn. 1). Na ekonomickou prosperitu města a jeho zázemí měly silný vliv i bouřlivé události třicetileté války. Na přelomu let 1623 a 1624 tu kvartýrovaly jednotky pluku Julia Jindřicha, které si násilím od obyvatelstva vymáhaly další požitky. Nechvalně proslulý byl rytmistr Beneda (Líva 1951, 423, 532, 537, 545, 624). V roce 1624 na Ronovsku kvartýrovaly kompanie Collaltova regimentu (Líva 1951, 676). Císařská vojska regionem protáhla i v roce 1626 (Líva 1953, 186-187). V roce 1627 byla v Ronově kvartýrována osmá kompanie Collaltova regimentu (Líva 1953, 203, 217). Díky obnovenému zřízení zemskému sledujeme další vlnu emigrace z náboženských důvodů, a to včetně majitele panství. Kolem roku 1631 byl uložen mincovní depot u Ronova nad Doubravou, objevený v roce 1845 (Nohejlová-Prátová 1957, 91). V roce 1634 se na Ronovsku nalézala část jízdního pluku S. Martiniho (Líva 1953, 321). V ř́ijnu roku 1646 se švédská jízdní jednotka pokusila zmocnit lstí nedalekého hradu Lichnice (Sedláček 1900, 42-43). 


\section{Metoda}

Při výzkumu antropogenních reliktů mikroregionu Ronova nad Doubravou využíváme širšího spektra nedestruktivních archeologických metod, které je možné provádět opakovaně a které přinášejí výchozí, podstatné a doplňující informace pro studium středověkého a raně novověkého osídlení v zalesněném prostředí a zemědělsky po staletí kultivované krajině. Při archeologickém výzkumu širšího zázemí Ronova nad Doubravou byly aplikovány metody, které umožnily srovnání a korelaci výstupů leteckého laserového skenování (dále LLS) a vizuálního nedestruktivního archeologického průzkumu s následným detailním geodetickým zaměřením vybraných antropogenních reliktů pomocí totální měřičské stanice LEICA TS06plus 5" R500 př́imo autory příspěvku. Nedestruktivními metodami identifikované antropogenní relikty jsou popsány podle formalizovaného deskriptivního systému, a to vazba na reliéf, tvar, rozměry (x, y, z), archeologické nálezy a současný stav (srov. Vařeka a kol. 2006).

Pro sledovaný mikroregion byly využity digitální modely reliéfu 5 . generace (dále DMR5G) vytvořené metodou LLS (poskytuje Český úřad zeměměřický a katastrální). Kvalita zachycených a interpretovaných archeologických reliktů pomocí DMR5G není na celém zkoumaném mikroregionu srovnatelná, avšak větší rozměry jednotlivých antropogenních a př́rodních reliktů můžeme snadno lokalizovat, identifikovat a vizualizovat při použití programů naprŕklad ArcMap10, RVT, SURFER nebo QGIS. Při archeologickém nedestruktivním výzkumu byly prováděny syntetické a analytické povrchové sběry. Povrchové sběry jsou aplikovány nejen v blízkosti antropogenních reliktů, ale i v širším okolí, zejména na polích (Smetánka 1977; Pehal 2003; Malina 2011, 111-114; 2012).

\section{Archeologický výzkum sídlištních struktur}

\subsection{Stusyně (obr. 3 a 4)}

Při nedestruktivním výzkumu zkoumané částečně zalesněné lokality v blízkosti kostela sv. Martina bylo identifikováno velké množství konvexních a konkávních objektů, které však nelze jednoznačně přiřadit $\mathrm{k}$ pozůstatkům středověkých a raně novověkých komponent zaniklé stř̌edověké vesnice. Značná koncentrace objektů se nachází jižně od kostela v uzavřeném prostoru nevýrazné ostrožny mezi řekou Doubravou a pramennou pánví. Vedle objektů, které můžeme považovat za relikty staveb a úvozových cest, jsou zde nepravidelné antropogenní útvary související s povrchovou těžbou kamene (patrně prospekční jámy) a větší vývraty. Některé antropogenní relikty byly nenávratným zpưsobem zničeny při výstavbě parkoviště, terénními úpravami okolí kostela a probíhající těžbou dřeva.

\section{Kostel}

Dominantu zaniklé vesnice tvoří dodnes stojící jednolodní kostel sv. Martina s věží umístěnou v západní části (obr. 3:1). Současný gotický presbytář nahradil románskou apsidu v polovině 14. století. V 80. a 90. letech 19. století došlo k úpravám kostela a rozšíření pohřebiště k severu (Birnbaumová-Jansová 1929, 325). V současnosti je stále dobře viditelná původní okrouhlá ohradní zed' na severní straně. Kostel je nejjižněji umístěným objektem z rozpoznaných antropogenních útvarů, které mohou souviset se zaniklou středověkou vsí. Patrně i symbolický význam měla výstavba kostela nad strmým svahem levého břehu Doubravky na východní straně ostrožny.

\section{Antropogenní relikty v intravilánu vsi}

Při rozboru reliéfních útvarů, zejména jejich tvarových vlastností, velikosti, prostorového uspořádání a umístění bylo vymezeno pět významnějších koncentrací objektů na ploše ca 1,6 ha. K první nejvíce zřetelné koncentraci řadíme pět antropogenních objektů umístěných na vyvýšené terase v jihozápadní části (obr. 4:2-6). Konkávní objekty jsou umístěny delší stranou ve 




Obr. 3. ZSV Stusyně. Celkový plán. Digitální model reliéfu sídlištního komplexu. 1 - kostel sv. Martina; 16 - relikt mlýna; 17 - náhon; šipkou označena vodoteč. Vytvořeno v programu ArcMap10.

Abb. 3. Mittelalterliche Dorfwüstung Stusyně. Gesamtplan. Digitales Reliefmodell des Siedlungskomplexes. 1 - St. Martinskirche; 16 - Relikt einer Mühle; 17 - Mühlgraben; mit Pfeil gekennzeichnet der Wasserlauf. Erstellt mit der Software ArcMap10.

směru sever-jih v jedné řadě za sebou. Všechny objekty mají velmi dobře rozpoznatelné hrany a téměř ploché dno. Objekt 2 je široká rýha o délce $25 \mathrm{~m}$ a šířce $4 \mathrm{~m}$ ve tvaru obráceného L. Šírka dna objektu se pohybuje v rozmezí od 1 do $1,5 \mathrm{~m}$. Hloubka objektu dosahuje 0,2 až $1 \mathrm{~m}$ od povrchu současného terénu. Na protější straně se nachází náznak obdobné rýhy o maximální délce $7 \mathrm{~m}$. V okolí objektu 2 se nachází drobné konkávní objekty. Interpretovat tento objekt je obtížné, 


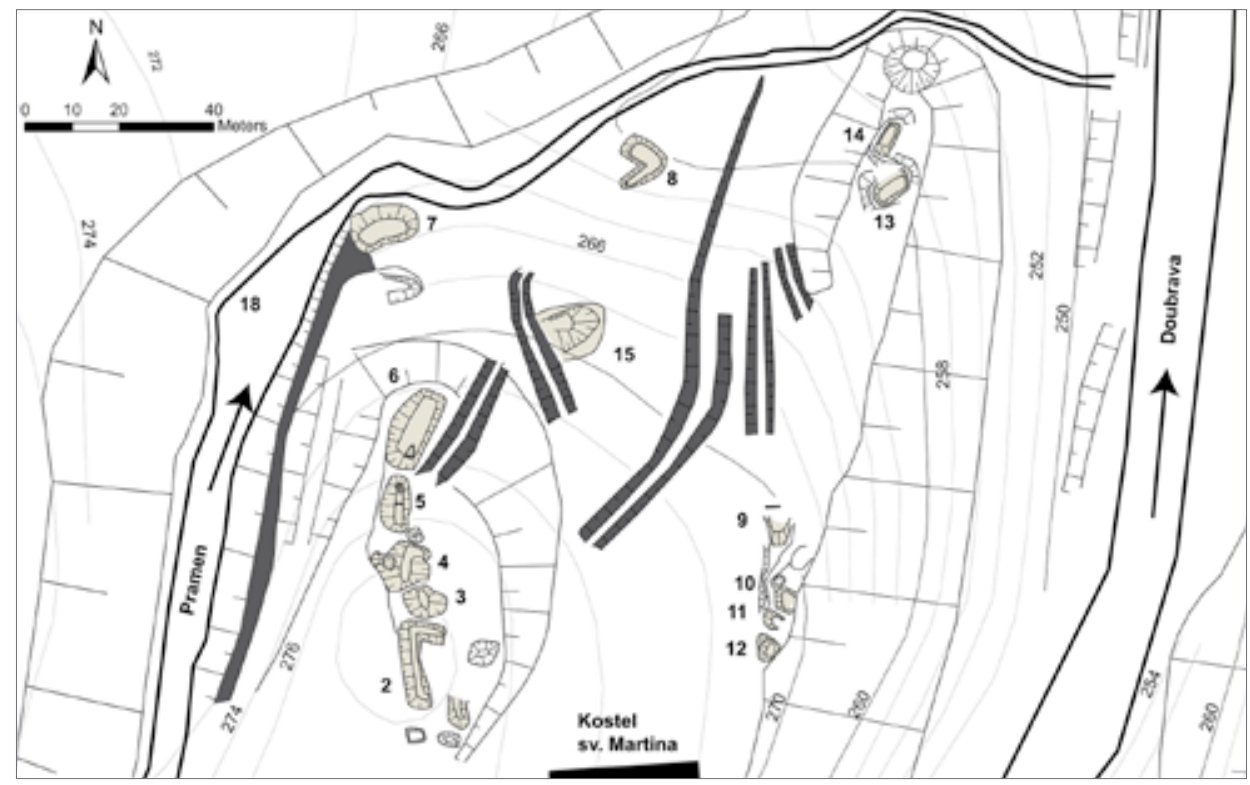

Obr. 4. ZSV Stusyně. Půdorysný plán. Sídlištní objekty - světle šedá; úvozové cesty - tmavě šedá; šipkou označeny vodoteče. Vytvořeno v programu ArcMap10.

Abb. 4. Mittelalterliche Dorfwüstung Stusyně. Grundrissplan. Siedlungsobjekte - hellgrau; Hohlwege - dunkelgrau; mit Pfeil gekennzeichnet die Wasserläufe. Erstellt mit der Software ArcMap10.

protože se mohlo původně jednat o zahloubenou stavbu, která byla zasypána při úpravách kostela a lesní cesty. Objekt 3 má téměř čtvercový tvar o rozměrech $7,1 \times 7 \mathrm{~m}$ a hloubce až $1,2 \mathrm{~m}$. V těsné blízkosti se nachází objekt 4 , který má taktéž téměř čtvercový půdorys, jeho rozměry jsou $9,7 \times 10 \mathrm{~m}$ a hloubka od 0,6 do $1,1 \mathrm{~m}$. Objekty 3 a 4 tvořily patrně jednu velkou zahloubenou stavbu o délce až $17,1 \mathrm{~m}$ rozdělenou nevýraznou přičkou uprostřed. Oba objekty jsou silně poškozeny na východní straně vývraty a povrchovou těžbou kamene. Objekt 5 má obdélný tvar o rozměrech $11,1 \times 6,1 \mathrm{~m}$ a hloubce od $0,4 \mathrm{~m}$ do $1,2 \mathrm{~m}$. Jižní část plochého dna objektu je mírně vyvýšená. Poslední, objekt 6 byl vyhlouben do mírného svahu orientace ve směru severozápadjihovýchod, je přizpůsoben charakteru terénu. Rozměry objektu jsou 17,7 × 8,5 m a hloubka od 0,3 do $0,9 \mathrm{~m}$. Dno je ploché a hrany objektu mírně převyšují přírodní terén. Všechny uvedené objekty lze interpretovat jako zahloubené části nadzemních staveb.

Druhá koncentrace, sestávající ze dvou objektů, se nachází v severovýchodní části zkoumaného polygonu. Objekty se nachází v blízkosti pramenné pánve. Objekt číslo 7 je mírně konvexního charakteru a obdélného tvaru s orientací delší strany východ-západ. Rozměry objektu jsou 14,5 × 8,5 m. Dochovaná výška objektu je $0,4 \mathrm{~m}$. Na západní straně tento antropogenní útvar splývá $\mathrm{s}$ terénem. Objekt se nachází na nevýrazné terase, která zároveň v tomto bodě zužuje pramen. Nad tímto objektem se nachází uměle vytvořená záchytná nádrž (obj. 18). K objektu směřuje ze západní strany cesta, na které byla nelegálně detektorářem vyzvednuta středověká podkova a zanechána na místě. Tento objekt můžeme interpretovat jako relikt nadzemní stavby, zcela hypoteticky mlýnu. Objekt 8 má nepravidelný tvar úhlové dispozice o celkové délce $20 \mathrm{~m}$ a šířce $5,6 \mathrm{~m}$. Objekt je špatně rozpoznatelný v terénu. $V$ obou př́ípadech se jednalo o relikty nadzemních staveb, bez zahloubených částí, což lze vysvětlit blízkostí pramenné pánve.

Třetí významnou koncentraci představují objekty 9-12 umístěné v řadě za sebou, které se nachází v jihozápadní části na vrcholku svahu nad řekou Doubravou. Jsou to konkávní objekty oválného tvaru. Zahloubené objekty jsou značně poškozeny erozí. Objekty mají na délku i šiřku 
v rozmezí 4 až 4,5 m. S opatrností je lze interpretovat jako torza po zahloubených stavbách. Jižně v těsné blízkosti zahloubeného objektu 9, který byl poškozen při těžbě dřeva, byla odkryta řada vyskládaných kamenů o délce $3 \mathrm{~m}$.

Na severozápadní straně zkoumané lokality byly identifikovány dva konkávní objekty. Oba měly obdélný tvar. Delší strana objektu 13 má orientaci severovýchod-jihozápad. Objekt dosahuje délky $10 \mathrm{~m}$ a šířky $5 \mathrm{~m}$. Dochovaná hloubka se pohybuje od 0,1 do $0,4 \mathrm{~m}$. Objekt 14 má orientaci sever-jih. Jeho rozměry jsou $9,5 \times 4,2 \mathrm{~m}$ a hloubka od 0,1 do $0,4 \mathrm{~m}$. Objekty lze interpretovat jako pozůstatky jedné nebo dvou nadzemních staveb, které se přizpůsobily možnostem prírodního terénu. V těsné blízkosti objektů se nachází nevelký lom na kámen.

Poslední koncentraci objektů tvoří úvozy umístěné v centrální části zkoumaného polygonu. Části úvozových cest dosahovaly hloubky až $1,8 \mathrm{~m}$. Součástí jedné úvozové cesty byl i silně poškozený konkávní objekt 15 o rozměrech ca $12 \times 11 \mathrm{~m}$ a hloubce od 0,3 do $1,6 \mathrm{~m}$. Tento zahloubený objekt můžeme s určitou mírou opatrnosti interpretovat jako relikt nadzemní stavby.

\section{Relikt mlýna}

Ve vzdálenosti $170 \mathrm{~m}$ severně od intravilánu vsi se dochoval dobře rozeznatelný obdélný objekt. Objekt 16 je orientován delší stranou, o délce $12,3 \mathrm{~m}$, ve směru severozápad-jihovýchod. Šiřka objektu je $6,9 \mathrm{~m}$. V současnosti objekt spočívá na stejné úrovni jako přírodní terén, avšak nelze vyloučit, že byl původně zahloubený. Zachovaly se i relikty stěn o šířce až $0,3 \mathrm{~m}$ a výšce od 0,2 do $0,4 \mathrm{~m}$. V jižní části objektu se dochoval i náznak rozdělení stavby př́ičkou. Tento objekt je zřejmě pozůstatkem nadzemní, patrně vícedílné stavby s relikty podezdívky po obvodu, kterou můžeme interpretovat jako mlýn nebo jeho součást. Plasticky to dokládají zbytky vodního náhonu (obj. 17) v těsné blízkosti reliktů interpretovaných jako pozůstatky mlýna (srov. obr. 3).

\section{Interpretace terénni situace}

Zaměřené antropogenní útvary odpovídají, svými tvarovými vlastnostmi i rozměry, reliktům známým ze zaniklých pozdně středověkých a raně novověkých vsí a dvorů v Železných horách (Musil-Netolický 2012; 2014b; 2015b; 2016a; 2018), ale i srovnatelným objektům ze vzdálenějších lokalit - ZSV Nevězeň, ZSV Bukov a ZSV Rovný (srov. Vařeka 2008; 2016; 2014; Novák-Vařeka 2016). Celkové rozmístění zaměřených antropogenních reliktů vytváří ze čtyř stran téměř uzavřenou plochu. Na jižní straně uzavírá tento komplex symbolicky kostel sv. Martina. Nejhlubší, nejrozměrnější a nejlépe dochované jsou objekty 3-6 na východní straně zkoumané lokality. Obdobné útvary lze předpokládat na protější, opět vyvýšené straně, avšak tam se dochovaly - vlivem eroze, těžby dřeva a výstavby lesní cesty - pouze jejich nepř́liš čitelná torza. Středem zaniklé vsi procházely svazky komunikací v podobě hlubokých úvozových cest. Ze všech zdokumentovaných reliktů je nejlépe dochovaným solitérně umístěný mlýn na spodní vodu, který zanikl pravděpodobně jako poslední na počátku novověku. Hypoteticky se mohlo jednat o jeden ze dvou mlýnů, které zmiňuje zakládací listina města Ronova nad Doubravou z roku 1307 (RBM IV, 824 č. 2124; srov. Štěpán-Šulc 2013, 122), zcela jistě však jde o mlýn, který je zmiňován při majetkové transakci v roce 1578 ,pod Štusinou slove Podskalni“" (Profous-Svoboda 1957, 226). Součástí zaniklé vesnice byla i vodní nádrž (obj. 18), která se nachází v pramenné pánvi. Pouze na základě povrchového průzkumu Zdeňka Smetánky (1977) můžeme uvažovat o rozmístění dalších sídlištních objektů jižně od kostela na místě dnešní louky. Prokázat tuto hypotézu by mohl prozatím jen geofyzikální průzkum. Při vizuálním průzkumu nebyly zjištěny na jižní straně za kostelem sv. Martina žádné další antropogenní relikty, které bychom mohli jednoznačně interpretovat jako sídlištní objekty.

\subsection{Povrchové sběry}

\section{Použité metody analýzy}

V nejbližším okolí kostela sv. Kříže bylo postupně provedeno vícero průzkumů metodou povrchových sběrů keramiky. První publikovaný povrchový průzkum byl v zázemí kostela 
Sv. Kř́iže proveden v roce 1977 Zdeňkem Smetánkou a Jiřím Škabradou. Z metodického hlediska se jednalo o tzv. syntetický povrchový sběr, s jednoduchou definicí ploch s vyšší kvantitou keramických nálezů určitých kategorií. Tyto plochy jsou odhadem definovány již v terénu a zpravidla ztotožněny s místy zaniklých usedlostí. Tímto způsobem autoři především situovali zaniklou sídelní buňku na pole jihozápadně pod kostelem sv. Kříže.

V letech 2010-2014 realizoval O. Malina analytické povrchové sběry na všech dostupných (oraných) plochách v zázemí kostelů sv. Kříže a sv. Martina (obr. 5). Jejich hlavním cílem bylo prrispět k poznání sídelní struktury pomocí analýzy prostorové distribuce a míry rozptylu keramiky nalezené na povrchu polí. Prvním konkrétním cílem bylo zjištění vypovídací schopnosti povrchových keramických souborů, tedy to, zda je keramika na povrchu pole přítomná a zachovaná do té míry, abychom z jejího výskytu mohli rekonstruovat sídelní topografii a využití ploch v minulosti. Druhým konkrétním cílem byla lokalizace předpokládaných menších sídlišt', odpovídajících modelu osídlení rozptýleného na více míst a také ověření výsledků starších sběrů Z. Smetánky a J. Škabrady. Třetím konkrétním cílem bylo získání představy o využití ploch v minulosti včetně odhadu vlivu hnojení polí na distribuci keramického odpadu.

Základem vyhodnocení distribuce a míry rozptylu keramiky z povrchových sběrů je kombinace dvou nástrojů - GPS pro organizaci sběru a lokalizaci nálezů a GIS pro správu, evidenci

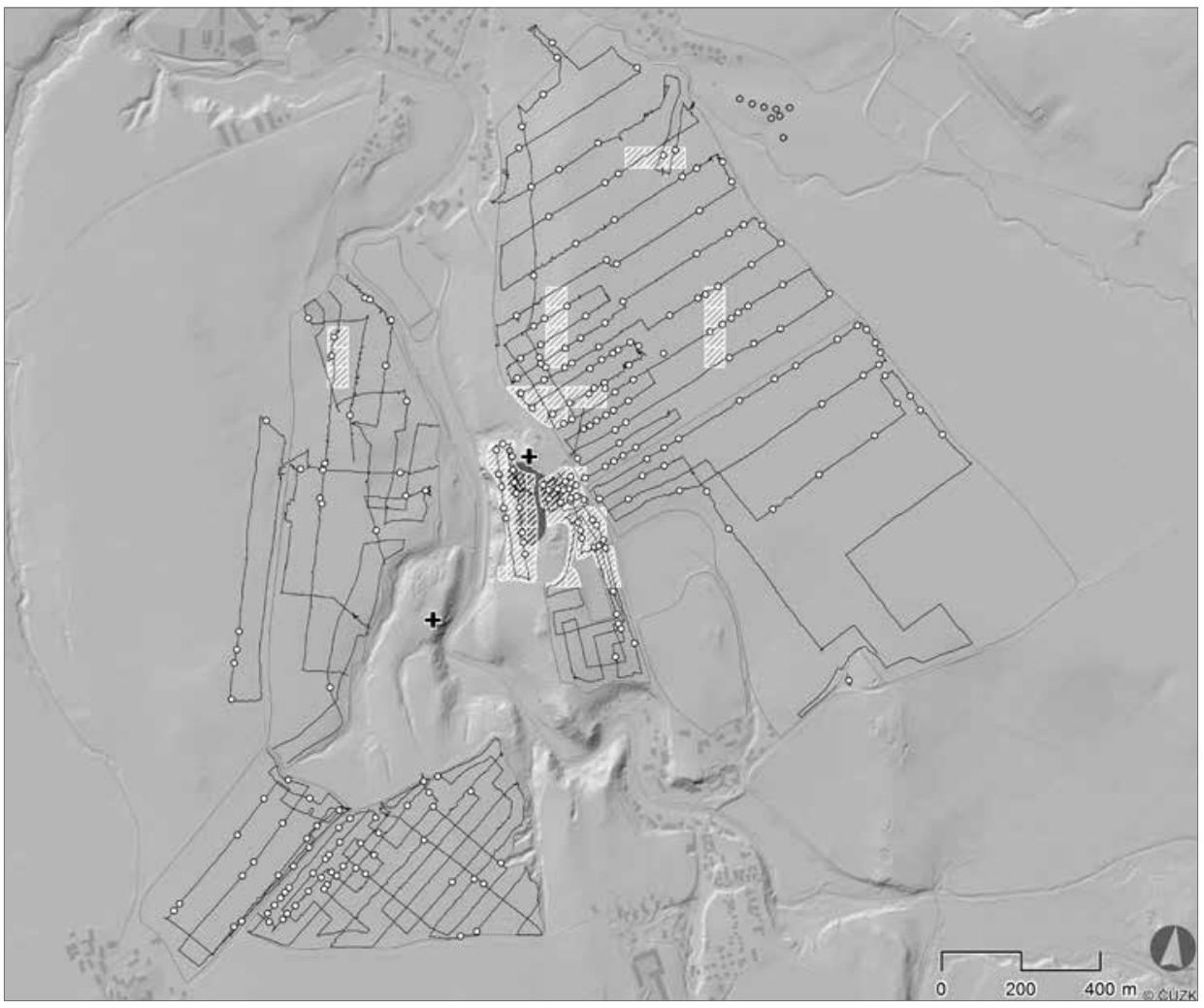

Obr. 5. Rozsah povrchových sběrů v liniích (černé linie a bílé body) a ve čtvercích (bíle šrafované čtverce). Černou šrafurou označen rozsah syntetických sběrů Z. Smetánky a J. Škabrady, křižzem poloha obou kostelů. Zdroj podkladových dat Č́́ZK Praha.

Abb. 5. Umfang der Liniensurveys (schwarze Linien und weiße Punkte) und der Rastersurveys (weiß schraffierte Raster). Schwarz schraffiert wurde der Umfang der von Z. Smetánka und J. Škabrada durchgeführten synthetischen Surveys, mit einem Kreuz die Lage der beiden Kirchen. Quelle Basisdaten des Tschechischen Amtes für Landesvermessung und Kataster Prag. 
a analýzu získaných dat. Organizace sběru keramiky byla v zásadě obdobná jako např́íklad na lokalitě Jenišovice (srov. Čapek-Malina-Rytíř 2013). Povrchové sběry u Ronova však byly na rozdíl od Jenišovic realizovány s využitím dvou metod, sběru v liniích a ve čtvercích.

Pro základní představu o charakteru povrchových souborů byl využit průzkum v liniích. Ten záhy ukázal, že keramika je zachovaná stále poměrně dobře, a proto byly touto více extenzivní metodou sběru alespoň částečně pokryty všechny dostupné plochy v nejbližším okolí kostelů. Míra pokrytí ploch sběrovými liniemi byla korigována na displeji GPS, kde byly vždy zobrazeny všechny již prochozené linie. Tento postup umožňuje alespoň přibližně rovnoměrné pokrytí zkoumaných ploch. Vzhledem k extenzivnímu charakteru sběru v liniích bylo rezignováno na zcela homogenní intenzitu průzkumu. Celkem bylo takto prochozeno 43,5 kilometru sběrových tras. Keramika byla při tomto průzkumu sbírána selektivně, jednalo se primárně o sběr veškeré „makroskopicky středověké“ keramiky a makroskopicky mladší keramika byla sbírána pouze v místě nálezu (v okruhu do ca 3 metrů) keramiky starší. Sbírány byly i všechny druhy keramiky, u kterých bylo přímo v terénu podezření, že mohou být středověkého původu. Každý nález byl evidován pomocí GPS (Trimble Geoexplorer 6, Pathfinder Pro XH s jednotkou Recon) s průměrnou přesností 1-3 metry.

Ve vybraných segmentech sledovaného území (obr. 5) byl realizován sběr ve čtvercích. Zde již byla sbírána veškerá keramika s výjimkou porcelánu a zjevně recentních materiálů. Použitá metoda pracuje analytickým způsobem s vytvořením základní polygonové čtvercové sítě (hrana 50 metrů) pro celou lokalitu, s oříznutím této sítě podle ploch dostupných polí a s prováděním povrchových sběrů již jen v rámci vybraných čtverců. Poloha nálezů a poloha sběrače na poli je registrována pomocí GPS/GNSS. Každý čtverec je při sběru procházen 10 minut nebo dobu úměrně kratší, pokud je čtverec na kraji pole a nemá plochu kompletní. Tímto způsobem bylo dosud sbíráno 58 čtverců.

Klíčem k nedestruktivnímu poznání zaniklé sídelní topografie je v našem př́ípadě lokalizace keramiky, která prostorově koreluje s místy zaniklého osídlení. Poměrně rozsáhlý problém distribuce keramického odpadu v rámci raně středověké sídelní jednotky byl již opakovaně diskutován (např. Meduna 1992, 284; Kuna 2004, 316; Bintliff-Snodgrass 1988, 503-516). Pro účel této práce předpokládáme tři základní typy vzájemných prostorových vazeb mezi osídlením a keramickým odpadem. Primární, kdy se keramika dodnes vyskytuje na místě minulého osídlení (usedlostí), a sekundární, kdy je keramika na místo svého dnešního výskytu vyvezena nebo zanesena erozí ze sídla ležícího jinde, nejčastěji s hnojem. Třetím typem je nejasná situace, kdy je původ keramiky neznámý a může patřit pod oba výše zmíněné druhy původu. Analýza rozptylu může ukázat na kategorie či technologické třídy, u kterých má smysl usuzovat na rozsah zaniklého osídlení a př́ípadně, je-li získaná chronologie použitelná, i na časové určení sídelní transformace.

U keramických technologických tříd se sekundárním původem může rozptyl keramiky vypovídat pouze o způsobu či míře hnojení, u kterého nelze vyloučit ani jeho záměrné navážení jen na určitá konkrétní místa. Vzhledem k rozložení „hnojových“ tř́id, které je většinou velmi blízké jejich simulovanému náhodnému rozdělení (viz níže), tomu tak patrně není. Rovněž pravděpodobná dlouhodobost procesu hnojení nahrává spíše rovnoměrnému rozložení než koncentracím, které mají navíc tendenci k postupnému rozptylu, protože nejsou pravidelně zásobovány nálezy ze zahloubených archeologických objektů. V prŕípadě analýzy rozptylu je vždy třeba přihlížet k celkovému kontextu všech zkoumaných keramických tř́id, nejen k jednotlivým hodnotám.

Jisté koncentrace může sekundárně vytvářet i keramika navážená spolu s jiným odpadem za účelem zpevnění povrchu polních cest. Po rozorání těchto cest se pak dané zlomky mohou dodnes nacházet na povrchu pole. I zde však platí možnosti analýzy rozptylu založené na kvantitách. Je otázkou dalšího výzkumu, zda se podaří někde tento původ keramiky vymezit, například lineárním tvarem plochy s vyšší koncentrací. Rovněž je třeba uvést, že velká část zaniklých stabilnějších, a tedy udržovaných komunikací se v nějaké formě projevuje bud' na digitálním modelu terénního reliéfu nebo v mapách pozemkového katastru či katastrální mapě. 
Vzhledem $\mathrm{k}$ opakovaným sběrům prováděným různými metodami a autory se nabízí srovnání jejich výsledků. Porovnáme-li výsledky všech tří metod, analytického sběru v liniích i čtvercích a staršího sběru syntetického, na poli č. 10 jihozápadně pod kostelem sv. Kř́že, je shoda u obecně stř̌edověké keramiky dobře patrná. Vyhledávací linie zachytily hlavní kumulace na stejných místech a v podobném rozsahu jako sběry ve čtvercích tam, kde byly realizovány. Prostorový rozsah výskytu středověké keramiky, zachycený šrafurou Z. Smetánkou a J. Škabradou (obr. 5) v tomto textu, se podobá výskytu modelovanému funkcí Kernel Density (jádrové vyhlazení, dále KD). Všechny tři metody se dobře shodují v lokalizaci maximálních koncentrací. Výrazný rozdíl mezi syntetickým a analytickým sběrem je však v zachyceném celkovém rozsahu jednotlivých skupin středověké keramiky. Dále je pravděpodobné, že metoda syntetického sběru je schopna zachytit jen výrazné koncentrace a více či nepravidelně rozptýlené plochy jsou mimo její rozlišovací schopnost. Nevýhodou je i chybějící představa o rozsahu provedených povrchových sběrů.

\section{Vyhodnocení nálezů (obr. 6-8)}

Celkem bylo při povrchovém průzkumu získáno 1149 kusů o celkové hmotnosti $6462 \mathrm{~g}$. Hlavní složku souboru tvoří zlomky keramiky a kachlů (1 121 ks, 6217 g). Pravěká štípaná kamenná industrie je zastoupena dvěma kusy, broušená kamenná industrie třemi zlomky brousků, struska třemi kusy, osteologický materiál jedním zlomkem zubu a dalšími recentními nálezy, souhrnně pěti kusy.

Nejlépe uchopitelný a datovatelný je soubor nalezené keramiky. Keramiku lze na základě makroskopicky postižitelných vlastností ${ }^{2}$ rozčlenit do 26 základních technologických keramických tř́́d (dále jen KT), které mají rovněž chronologický význam (Frolík-Musil-Sigl s. d.). Typologie okrajů byla převzata podle třídění M. Zápotockého (1978, obr. 5).

Nejstarší zjištěné zlomky keramiky náleží KT 101 (Frolík-Musil-Sigl s. d.), kterou je možné datovat do pozdně laténského období $(2 \mathrm{ks})$. Analogickou keramiku nalézáme např́íklad na oppidu v Hradišti u Českých Lhotic (srov. Danielisová 2010). Jedná se tak o další doklad osídlení doby laténské na katastru Ronova nad Doubravou, kterému bude detailní pozornost věnována v samostatné studii. Nejstarší středověkou komponentu souboru představuje tmavě hnědošedé hrubší silnostěnné obtáčené zboží (KT Ro3) doložené v 37 kusech. V jednom případě se dochoval jednoduchý zaoblený okraj (typ 112). Z výzdoby je zastoupena oběžná šroubovice (obr. $8: 3 / 7,3 / 8,3 / 9$ ), torzo vlnice a ryté linie provedené hřebenovitým nástrojem (obr. 7:2/7). Toto zboží je možno řadit na závěr mladohradištního období a doposud nebylo na jiných lokalitách Chrudimska registrováno. Patrně stejného stáří je oxidačně pálené silnostěnné a obtáčené zboží (KT Ro6), doložené v 33 př́ipadech. Dochoval se jeden vytažený okraj s horní plochou rovnou, vnější prožlabenou (typ 343 - obr. 6:1/2) a na jednom zlomku výzdoba v podobě široké oběžné šroubovice (obr. 7:2/8). Podobně jako v předešlém prŕípadě také KT Ro6 doposud jinde na Chrudimsku neregistrujeme. Do přelomu 12. a 13. století řadíme výskyt charakteristické keramiky s prŕměsí grafitu (KT Ro16). Na území okresu Chrudim známe importovanou grafitovou keramiku z Chrudimi a jejího bezprostředního okolí (např. z Chrudimi, Filištínské a Hradební ulice - Frolík-Sigl 1999; Frolík-Musil-Sigl s. d., KT CRF 8 a 208; z hradu Rabštejnka - Musil 2009, KT Ra 21; z prostoru zaniklého benediktinského kláštera v Podlažicích, KT Podlažice 5 Frolík-Musil-Sigl s. d.; ze Stolan - Musil 2012, 211, obr. 16:4, 17:3-4; od kostela sv. Martina v Hrochově Týnci - Frolík-Stránská-Švédová 2018, 988), z okolí Kovářova a Hoješína (KT Kovářov 2 - Musil-Netolický 2016, 286) a ze Skutečska (u kostela sv. Václava v Lažanech Frolík-Musil-Sigl s. d.). V našem souboru je zastoupena sedmi kusy, dochoval se i jednoduše profilovaný zaoblený okraj (typ 112 - obr. 8:3/1).

Pro období 13. a polovinu 14. století je poměrně dominantní obtáčené oxidační zboží oranžových tónů (TK Ro2), které je doloženo v celkem 197 př́ípadech. Zboží obsahuje vyšší procento

1 Jedná se o zlomky ploché střešní krytiny, křídového skla, asfaltového terče a zbytků munice z 2. světové války.

2 1. barva, 2. ostřivo, 3. barva lomu, 4. výpal, 5. povrch, 6. afinita s jinými keramickými tř́íami. 

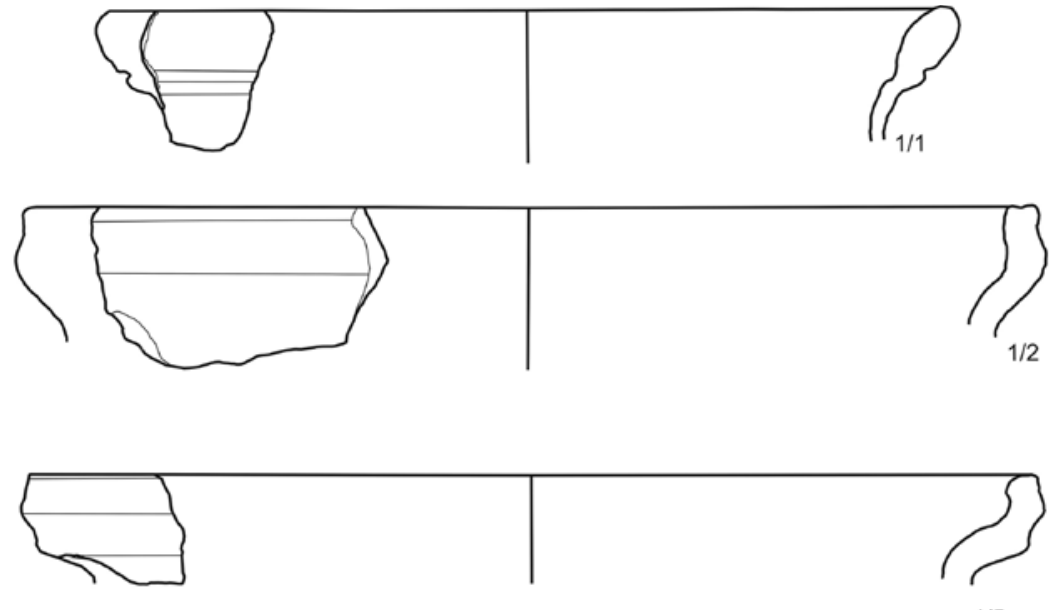

$1 / 5$
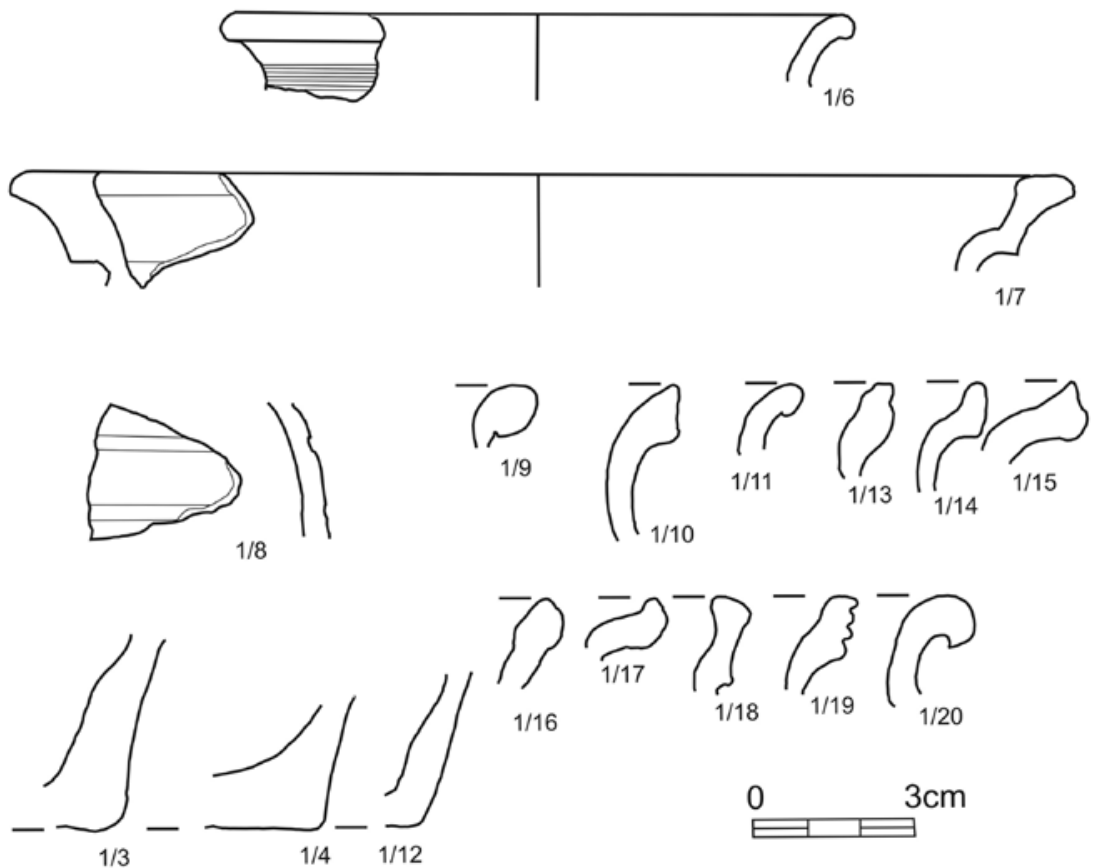

Obr. 6. Ronov nad Doubravou. Výběr keramiky z analytických sběrů. Kresba J. Musil.

Abb. 6. Ronov an der Doubrava. Keramikauswahl von den analytischen Surveys. Zeichnung J. Musil.

slídy, což je charakteristický znak místní keramické produkce. Toto zboží nalézáme i v areálu ZSV pod Sečskou přehradou (KT Seč 7, Musil v tisku). V rámci této třídy registrujeme vyšší variabilitu v rámci okrajové profilace hrncovitých nádob, kdy jsou zastoupeny varianty římsovitých, vytažených, nepravých okruží, ovalených s vnitřním prožlabením a kyjovitých (typ 221 - 1×; 312 - 1×; 343 - 3×; 349 - 1×; 374 - 1×; 431 - 1×; 444 - 1×; 852 - 1× - obr. 6:1/1, 1/17; obr. 7:2/27, 2/4, 2/23; obr. 8:3/10). Tvarové spektrum nádob doplňují zlomky mís (typ M221 - 1×; 
M323 - 2×) a zvonovitých pokliček (typ Pk13). Z výzdobných prvků byla v pěti prrípadech registrována oběžná šroubovice (obr. 8:3/4, 3/5, 3/6, 3/13, 3/14), značka na dně nádoby v podobě kř́iže v kruhu (?). Na jednom zlomku byly registrovány stopy po sekundárním provrtu. Velikost zlomku vylučuje možnost rozhodnout, zda se jednalo o reparační otvor, nebo zda byl zlomek keramiky druhotně užit jako přeslen.

Do stejného časového období můžeme datovat rovněž keramiku tmavších tónů s písčitým ostřivem a výraznou příměsí hrubě drcené slídy (KT Ro13). I tato keramika je charakteristická pro oblast Č́slavska (Tomášek 1995, 444-454; Pavlů 1982, 75-160; Pehal 2003, 3-17), Golčovojeníkovska (Pehal 2001, 5-9; 2001a, 96-100; 2006, 124-139), Havlíčkobrodska (Rous-Veselý 1981, 16-20, tab. 1) a všeobecně železnohorské oblasti (srov. ZSV Bolešov, KT Bolešov 1 Musil-Netolický 2012; ZSV pod Sečskou přehradou, KT Seč 1 - Frolík 1989, 70-77; Musil 2007, 199-219; v tisku; v okolí Kovářova a Holína - TK Kovářov 4 - Musil-Netolický 2016; z hradu Strádova, KT Strádov 3 - Musil 2016, 58-59; tvrze Stoupec, KT Stoupec 3 - Musil-Netolický 2014; Trhová Kamenice, KT TK1 - Musil 2011, 59-104; Zkamenělý zámek na k. ú. Česká Cikánka - Frolík 1984, 24-26; Frolík 1989a, 6-7; Lány, k. ú. Kameničky u Hlinska - Frolík 1984, 13-14; Skutečsko - Frolík 1982, 9-10; Hlinecko - Frolík 1989a, 6-8; Perálec - nepublikováno), která je zastoupena 48 kusy. Její výskyt se kryje s 13. až první polovinou 14. století. V rámci tohoto keramického zboží registrujeme vyšší variabilitu v rámci okrajové profilace hrncovitých nádob, kdy jsou zastoupeny varianty jednoduše profilovaných okrajů, okrajů rrímsovitých, vytažených, nepravých okruží, ovalených s vnitřním prožlabením a kyjovitých (typ 112 - 1×; 231 -2×; 321 - 1×; $351-1 \times ; 431$ - 1×; 836 - 1× - obr. 6:1/13, 1/18; obr. 7:2/19, 2/35; obr. 8:3/2). V souboru byl registrován i zlomek ze zvonovité pokličky.

Celkem jedenácti zlomky je v souboru zastoupeno tmavě hnědé keramické zboží (KT Ro24), které známe i z jiných částí Chrudimska, konkrétně z hradu Strádova (KT Strádov 4 - Musil 2016, 58-59) či z prostoru podlažického klášteřiště (KT Podlažice 17, Frolík-Musil-Sigl s. d.). Okraje hrncovitých nádob byly profilovány ve formě vytažených okrajů (typ $345-1 \times$ ). Jeden zlomek nese výzdobu v podobě archaicky vyhlížejícího radélka (obr. 8:3/15), které se na Chrudimsku epizodicky vyskytuje ve 13 . století.

Technologicky vyspělejší, na rychlém hrnčířském kruhu vytáčené keramické zboží šedé až béžově šedé barvy (KT Ro1) je zařaditelné do 14. století. V souboru bylo registrováno 94 zlomkủ. Tomu odpovídá i okrajová profilace hrncovitých nádob zahrnující varianty nepravých okruží a ovalených okrajů s vnitřním prožlabením (typ 312 - 1×; $316-1 \times ; 325$ - 1×; 345 - 1×; 349 - 1×; $351-1 \times ; 352$ - 1×; $355-2 \times ; 412$ - 1× - obr. 6:1/15, 1/19; obr. 7:2/22; obr. 8:3/3, 3/11,3/22). Tvarové spektrum doplňuje i zlomek okraje misky (typ M521 - obr. 6:1/16). Ve výzdobě se objevuje oběžná šroubovice (obr. 7:2/1,2/2) a archaicky působící nehtové vrypy (obr. 7:2/9). Analogickou keramiku nalézáme i v Chrudimi, ve Filištínské (KT CRF 12 - Frolík-Sigl 1999) a Hradební ulici (KT 212 - Frolík-Musil-Sigl s. d.), v areálu ZSV pod Sečskou přehradou (KT Seč 5 - Musil v tisku) a na hradě Rabštejnku (KT Ra35 - Musil 2009).

Paralelně se vyskytuje i šedé vysoce na povrchu slídnaté zboží typu Zbyslavec (KT Ro9). Po technologické stránce se jedná o vyspělé zboží z větší části vytáčené na rychlém hrnčířském kruhu, které patrně produkovaly městské dílny snad z okruhu Čáslavi, Chotěboře či Ledče nad Sázavou. V souboru je zastoupena 56 kusy. Shodná keramika byla ve větší míře získána při záchranném archeologickém výzkumu Východočeského muzea v Pardubicích ve Zbyslavci (Cejpová 2008, 312), v menší míře z neznámé ZSV pod Sečskou přehradou (KT Seč 2 - Musil 2007; v tisku), z nedalekého hradu Ohebu (KT Oheb 10 - Frolík-Musil-Sigl s. d.), ze ZSV Bolešov (KT Bolešov 3 - Musil-Netolický 2012), a dále je zastoupena v Chrudimi, v Hradební ulici (KT 232 - Frolík-Musil-Sigl s. d.), v souboru keramiky z podlažického klášteřiště (KT Podlažice 6 - Frolík-Musil-Sigl s. d.), i z hradu Rabštejnka (KT Ra34 - Musil 2009). Z hlediska okrajové profilace registrujeme varianty římsovitých, vytažených okrajů a okrajů v podobě okruží (typ 211 - 1×; $343-1 \times ; 522-1 \times$ - obr. 6:1/10; obr. 7:2/34). Zvonovité pokličky jsou zastoupeny jedním zlomkem okraje (typ Pk21). Keramika byla zdobena oběžnou šroubovicí (obr. 6:1/8; obr. $7: 2 / 20,2 / 26,2 / 28,2 / 38)$. 

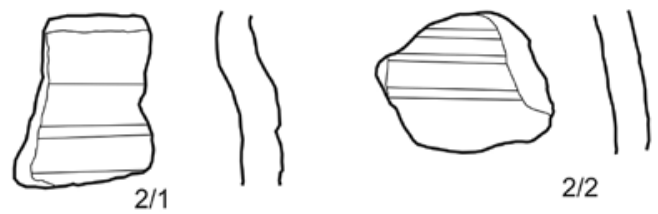
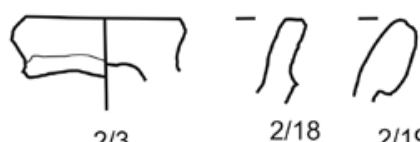

$2 / 3$ $2 / 19$

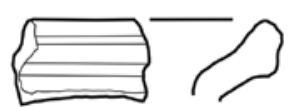

$2 / 4$
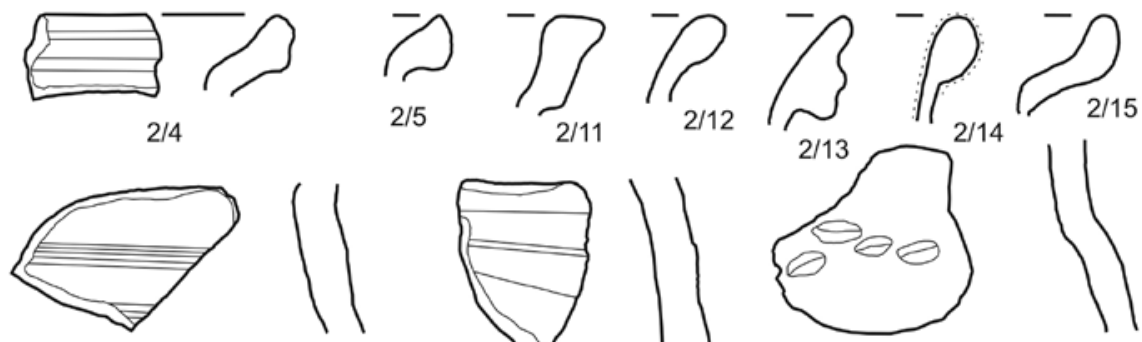

$2 / 7$
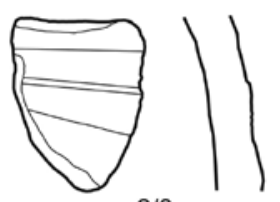

$2 / 8$
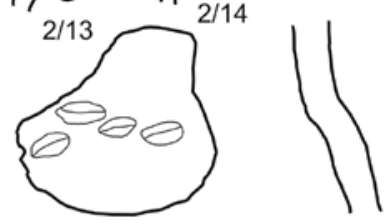

$2 / 9$

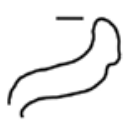

$2 / 22$
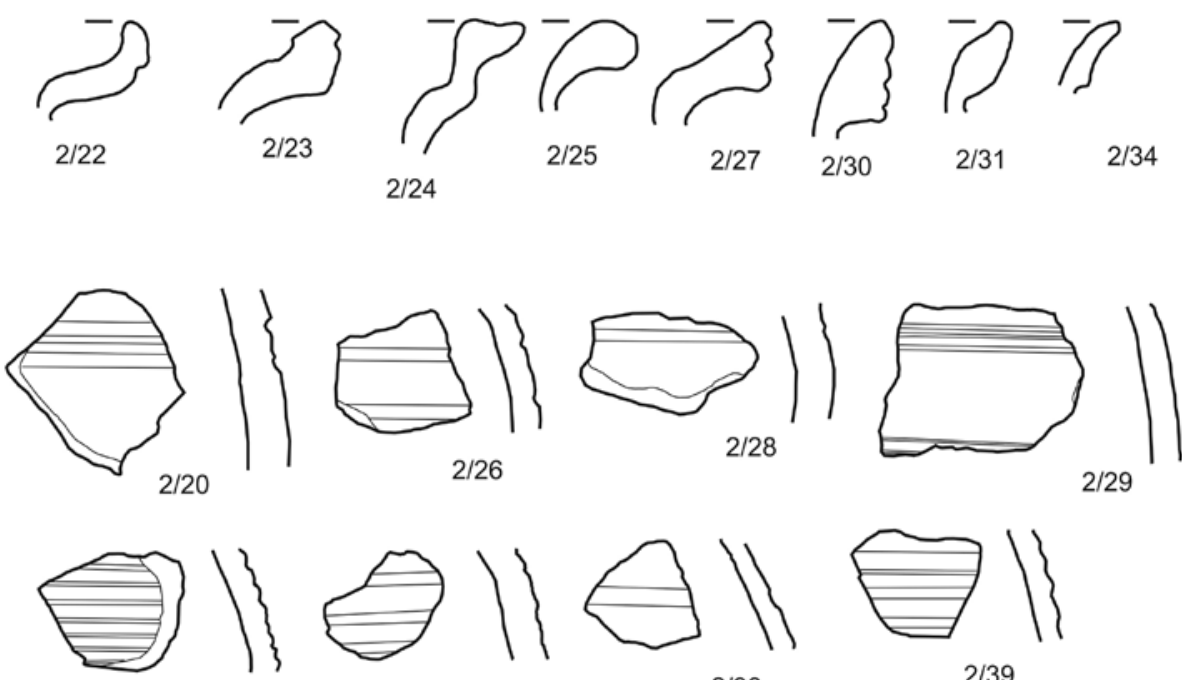

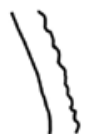

$2 / 33$



$2 / 37$

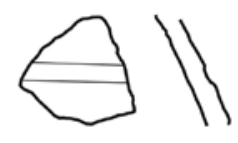

$2 / 38$



$2 / 39$

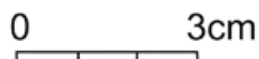

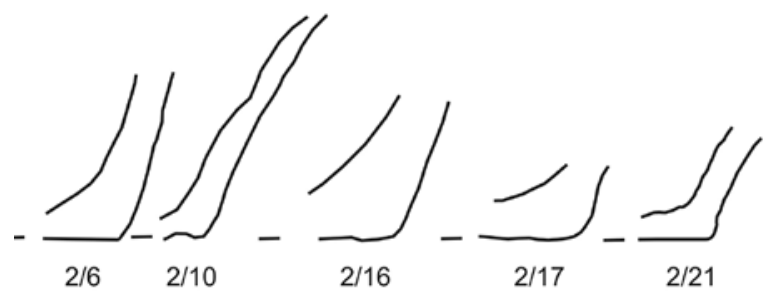

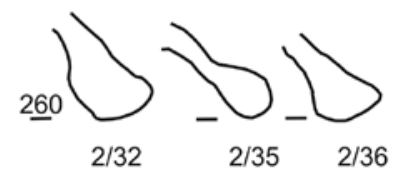

Obr. 7. Ronov nad Doubravou. Výběr keramiky z analytických sběrů. Kresba J. Musil.

Abb. 7. Ronov an der Doubrava. Keramikauswahl von den analytischen Surveys. Zeichnung J. Musil. 

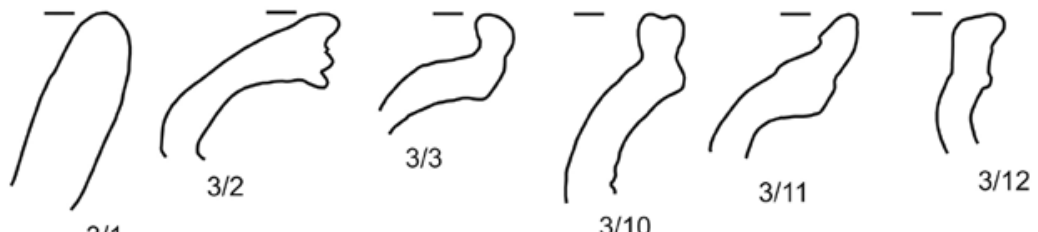

$3 / 1$
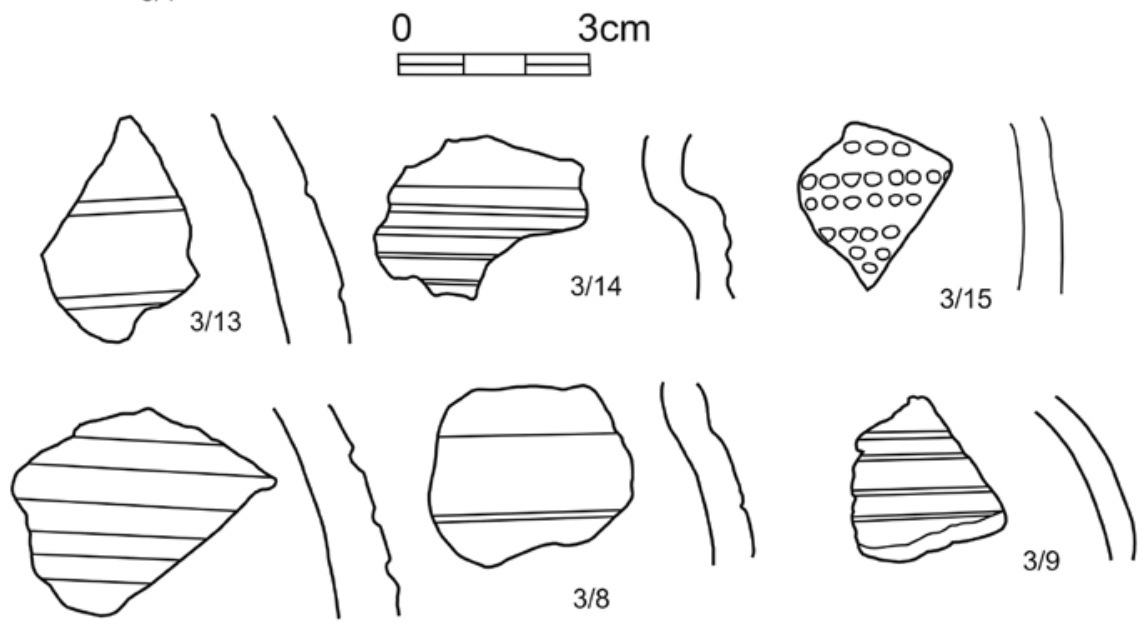

$3 / 7$

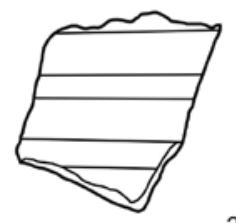

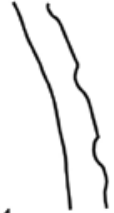

$3 / 4$
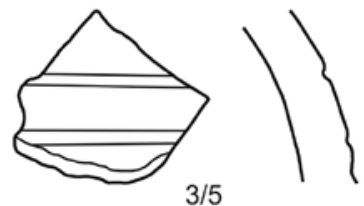



$3 / 6$

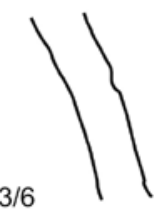

Obr. 8. Ronov nad Doubravou. Výběr keramiky z analytických sběrů. Kresba J. Musil.

Abb. 8. Ronov an der Doubrava. Keramikauswahl von den analytischen Surveys. Zeichnung J. Musil.

Do rozvinutého 14. a na počátek 15. století je možno zařadit kvalitní vytáčenou oxidační keramiku tříd Ro12 a Ro14. První zmiňovaná KT Ro12 je na Chrudimsku poměrně rozšířená. Konkrétně ji máme doloženu v Chrudimi samé (KT 219 - Frolík-Musil-Sigl s. d.), na hradech Rabštejnku (KT Ra16 - Musil 2009), Žumberku (KT Žumberk 16 - Frolík-Musil-Sigl s. d.), Nových Hradech (KT NH10 - Frolík-Musil-Sigl s. d.), ze ZSV pod Sečskou přehradou (KT Seč 9 - Frolík-Musil-Sigl s. d.) i z prostoru zaniklého benediktinského kláštera v Podlažicích (KT Podlažice 1 - Frolík-Musil-Sigl s. d.). V souboru čítajícím 44 zlomků registrujeme okraje v podobě nepravého okruží, zavinutých či kyjovitých okrajů (typ 351 - 1×; 357 - 1×; 385 - 1×; 386 - 1×; 833 - 1×; 836 - 1× - obr. 7:2/11,2/24), z výzdobných prvků se vyskytne vývalková šroubovice. Jeden zlomek byl sekundárně upravován broušením.

Méně četné je světlé oxidačně vypálené zboží s jemným přetaženým krupičkovitým povrchem (KT Ro14), celkem 27 kusů. Mezi okrajovými profilacemi hrncovitých nádob jsou zastoupeny okraje $\mathrm{v}$ podobě nepravého okruží, ovalené $\mathrm{s}$ vnitřním prožlabením a kyjovité (typ 343 - 1×; 431 - 1×; 543 - 1×; 836 - 1×; 851 - 1× - obr. 6:1/2; obr. 7:2/12, 2/30, 2/31). V souboru se vyskytují i okraje pokliček (typ Pk13 - 1×; Pk22 - 1× - obr. 7:2/32, 2/36). Podobně jako v případě předešlého zboží i tuto keramiku na Chrudimsku hojně nalézáme. Nechybí v Chrudimi, ve 
Filištínské (KT CRF 18 - Frolík-Sigl 1999) i v Hradební ulici (KT 218 - Frolík-Musil-Sigl s. d.), na hradech Rabštejnku (KT 36 - Musil 2009), Ohebu (KT Oheb 6 - Frolík-Musil-Sigl s. d.), na Nových Hradech (KT NH13 - Frolík-Musil-Sigl s. d.) i v areálu ZVS pod Sečskou přehradou (KT Seč 6 - Musil v tisku). Obě popisované keramické třídy odpovídají rozložení distribučních zón vymezených v minulosti Pavlem Vařekou (1998, obr. 1). Podle něj sever našeho území zaujímá oxidační tvrdě pálená keramika, jih šedá redukční a pruh mezi nimi tvoří hrubá stř̌edně tvrdě oxidačně pálená keramika. V tomto pásmu by se měla podle $P$. Vařeky nalézat ještě Č́slav a přilehlá východní část středních Čech (Vařeka 1998, 132).

Následující období 15. a 16. století je představováno jednak vyspělou redukční keramikou zdobenou radélkem (KT Ro4 - 124ks), jednak oranžovočervenou oxidačně pálenou keramikou s jemně plaveným keramickým těstem (KT Ro5 - 160 ks a KT Ro8 - 35ks). Obojí keramické zboží bylo vytáčeno na rychlém hrnčířském kruhu a bylo produkováno městskými hrnčířskými dílnami (srov. Musil 2009). Jedním zlomkem je zastoupeno dno z charakteristického loštického poháru (KT Ro22), dvěma zlomky okraje nádobkového kachle s pravoúhlým ústím (KT Ro25).

Období 17.-19. století je zastoupeno převážně glazovanými keramickými tř́dami Ro7, Ro10, Ro11, Ro15, Ro17, Ro18, Ro19, Ro20, Ro21 a Ro23.

\section{Vyhodnocení keramiky na základě analýzy rozptylu}

Cílem analýzy rozptylu jednotlivých keramických tříd bylo určení či naznačení jejich původu s pomocí informací o jejich prostorovém výskytu. Lze předpokládat (Malina 2011), že keramika pocházející ze zahloubených objektů či souvrství se na povrchu ornice vyskytuje ve větší až výrazně větší koncentraci než zlomky, které se na povrch dostaly v souvislosti s hnojením nebo jinými postdepozičními procesy.

Využity byly dvě základní metody, interpolace (metoda jádrového vyhlazení - Kernel Density, př́ípadně KD) pro vizualizaci prostorového výskytu a určení míry rozptylu pomocí směrodatné odchylky (Standard Distance, SD). Vzhledem k tomu, že obě patří spíše do oblasti metod zobrazovacích a průzkumových (Horák 2011, kapitoly 4.4.2, 2.4.2), bylo pro ověření validity výsledků realizováno i modelování náhodného rozptylu. V první části analýzy byla



Obr. 9. Míra rozptylu keramiky (graf hodnot SD) získané sběry v liniích. Řazeno dle hodnoty SD původních variant (černě). Randomizované varianty bíle.

Abb. 9. Verteilungsgrad der im Liniensurvey entdeckten Keramik (Diagramm der Standard Distance-Werte). Angeordnet gemäß den Standard Distance-Werten der ursprünglichen Varianten (schwarz). Randomisierte Varianten weiß. 
hodnocena keramika pocházející ze sběrů v liniích, které poměrně rovnoměrně pokryly všechny dostupné plochy v zázemí kostelů. Zde však zacílení na „makroskopicky středověkou keramiku“ omezuje srovnávací možnosti s novověkou keramikou. Ty jsou naopak dostupné u vyhodnocení sběrů ve čtvercích, které byly ale na druhou stranu provedeny jen na malé části sbíraných polí.

Výsledky analýzy sběrů v liniích jsou zobrazeny na grafu (obr. 9). Z 26 analyzovaných keramických tř́d bylo pro analýzu rozptylu použito jen 14 tříd s četností větší nebo rovnou 14 zlomkům, 12 tříd nebylo pro nízkou četnost analyzováno vůbec. Černé čtverce na grafu (obr. 9) vyjadřují svou hodnotou míru rozptylu (míru směrodatné odchylky, SD). Čím níže na svislé ose, tím více je skupina koncentrovaná, a naopak čím výše, tím je keramika v této skupině na poli více rozptýlená. Keramické tř́ídy jsou řazeny podle míry původního (nerandomizovaného) rozptylu. Bílé čtverce reprezentují randomizované varianty, jinými slovy to, jak by vypadal rozptyl dané keramické třídy při „dokonale náhodném“ rozptýlení. Randomizaci v našem případě provedl skript v programu ArcGIS, jehož autorem je Ing. Jakub Šilhavý.

Výsledky analýzy sběrů ve čtvercích (obr. 10) odpovídají v mnoha směrech výsledkům sběrů v liniích. Z 26 analyzovaných keramických tříd bylo pro analýzu rozptylu použito jen 12 skupin s výskytem v minimálně devíti čtvercích nebo větším. Zejména u nejvíce koncentrovaných trríd Ro3, Ro1, Ro2, Ro13 a Ro24 (řazeno dle hodnoty SD, černá elipsa na obr. 10) odpovídají hodnoty vstupní hypotéze o větší koncentraci starších skupin a zároveň větší hodnotě SD jejich randomizovaných variant. Naopak KT Ro19, Ro20, Ro5, Ro7, Ro4 a Ro10 jsou obecně na povrchu polí více rozptýlené anebo se jejich výskyt blíží modelovému náhodnému rozptylu. Pouze KT Ro12 (VS/PS, viz níže) se navržené základní klasifikaci z neznámého důvodu vymyká a vstupní hypotéza u ní neplatí.

Obě části analýzy lze shrnout tak, že keramické tř́idy tvoří zhruba tři základní skupiny. Pro první z nich je charakteristický mnohem větší rozdíl mezi původní a randomizovanou variantou (černé elipsy na grafech - obr. 9 a 10). U této keramiky předpokládáme největší vazbu na místa primárního výskytu. Na druhé straně spektra je keramika naopak více rozptýlená, než jak by to odpovídalo jejímu modelovanému náhodnému rozmístění (šedé elipsy). Nebo jinými slovy ta, jejíž randomizované varianty mají nižší nebo podobnou hodnotu SD vzhledem k variantám původním. Zde předpokládáme sekundární původ keramiky na povrchu polí. Keramické

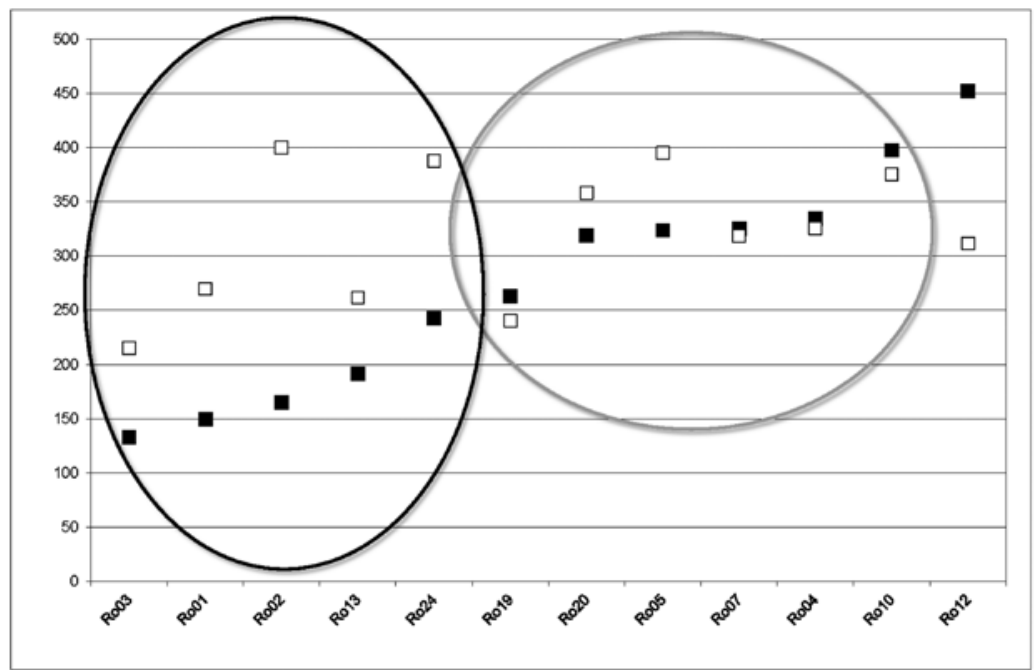

Obr. 10. Míra rozptylu keramiky (Graf hodnot SD) získané sběry ve čtvercích. Řazeno dle hodnoty SD původních variant (černě), randomizované varianty bíle.

Abb. 10. Verteilungsgrad der im Rastersurvey entdeckten Keramik (Diagramm der Standard Distance-Werte). Angeordnet gemäß den Standard Distance-Werten der ursprünglichen Varianten (schwarz). Randomisierte Varianten weiß. 
třídy ležící mezi těmito poměrně jasnými případy jsou zpravidla charakteristické podobným rozptylem původní i randomizované varianty anebo opačným poměrem hodnot SD obou variant a vstupní hypotéze částečně nebo vůbec neodpovídají. Jejich původ nebo důvod koncentrace, či naopak rozptylu jsou nejasné. Patří sem zlomky datované do středověku i do novověku (zejména KT Ro12 a dále Ro9 a Ro20).

V př́ípadě, že se snažíme lokalizovat zaniklé sídelní buňky středověkého původu, má největší smysl posuzovat jejich lokalizaci na základě nejvíce koncentrovaných tříd (viz obr. 11 a 12:a-d). Z porovnání s prostorovou distribucí jejich randomizovaných variant je dobře vidět jejich tendence ke shlukování. Druhou možností je sloučení chronologicky blízkých KT bez ohledu na míru jejich koncentrace (chronologicky RS4, KT Ro03 a Ro06, obr. 10 vlevo) anebo okruh 2 (VS, KT Ro01, Ro02, Ro09, Ro12, Ro13, Ro14, obr. 10 vpravo).

Podíváme-li se na výše zmíněné výsledky z hlediska transformace osídlení, nabízí se v první řadě srovnání s několika okolními regiony s publikovanými doklady proměny sídelní sítě. Základní model proměny osídlení, typický pro 13. století, lze zjednodušeně označit jako nukleační transformaci. Jinými slovy koncentraci více menších sídelních poloh do jednoho místa, jehož lokace byla z nějakého důvodu chápána jako výhodnější (Malina 2011, 49). Pro tento proces existuje řada publikovaných analogií. Geograficky nejbližší Třebonín je modelovým př́íkladem přesunu rozptýleného osídlení do jedné nukleované sídelní polohy, ke kostelu se středověkým původem (Smetánka-Škabrada 1975, 81). Stejná topografická situace, týkající se dvou poloh předcházejících dodnes existující vesnické jádro zformované před rokem 1300, byla doložena v případě Bylan u Kutné Hory (Klápště-Tomášek 2000, 175; Klápště 2005, 235) a Říkovic u Litomyšle (Charvát 1982, 226). Výhodou zdejších situací je i opora v písemných pramenech.

Větší prostorový záběr měly průzkumy na rovněž nedalekém Černokostelecku, kde jsou drobná sídla zaniklá opět před rokem 1300 čitelná jak prostřednictvím povrchových sběrů, tak i odkryvů. Díky nízké intenzitě zemědělské činnosti se zde mnohde dochovalo i členění pozemků, čitelné bud' v mapách stabilního katastru anebo v (digitálním modelem zviditelněném) terénním reliéfu (Klápště 1993; Smetánka-Klápště 1981; Malina 2015). Jako další regiony s vyšší mírou poznání sídlení transformace můžeme zmínit Jaroměřsko a Chrudimsko (Ježek 2007; Frolík-Sigl 1995). Bylo zde možné, většinou na základě intenzity nálezů, rozlišit i určitou hierarchii osídlených míst a jejich skupiny (sídelní komplexy) i lokální geografické limity, kde se přesun osídlení odehrával jen v omezeném prostoru typicky vymezeném jedním povodím. Za zmínku stojí i doložené krátkodobé osídlení některých sídelních poloh, které opět vynikne při srovnání s dlouhodobým přežíváním nedalekých lépe situovaných lokací.

Z publikovaných a ve značné zkratce zde uvedených analogií tedy vyplývá možný složitější obraz, než jakým je prostá prrítomnost několika jednotlivých a jasně vymezitelných raně středověkých sídelních buněk předcházejících vrcholně stř̌edověké lokaci. Jak bude ronovská situace vypadat $v$ konfrontaci s výše načrtnutými poznatky? Určitým společným jmenovatelem syntetických a námi realizovaných analytických sběrů je počet definovaných sídelních poloh. Jak již bylo řečeno, základem jejich interpretace jsou rozdíly v intenzitě výskytů keramiky, které pravděpodobně korelují s minulou intenzitou využití míst, kde je nacházíme.

\section{Závěr}

Na katastru současného města Ronova nad Doubravou se ve středověku nalézaly původně tři osady - Suchotlesky, Stusyně a Protivany. U dvou posledně zmiňovaných se dochovaly dodnes stojící románské kostely. Koncentrace osídlení v této oblasti je vysvětlitelná brodem u řeky Doubravy, kudy procházela tzv. Libická stezka. Řeka Doubrava zároveň představovala hranici mezi majetky vilémovského kláštera a panstvím Lichtenburků. Na klášterním levém břehu patrně o něco později vznikla ještě osada Suchotlesky. Na pravém břehu řeky u ZSV Protivany vzniklo trhové místo, výhodně situované při říčním brodu. Razantní zásah do zdejší sídlištní struktury znamenalo založení města Ronova nad Doubravou. Město nejenže zaujalo část katastru vsi Protivany, ale ještě usurpovalo trhové místo. Tím patrně došlo i k určitému posunu 

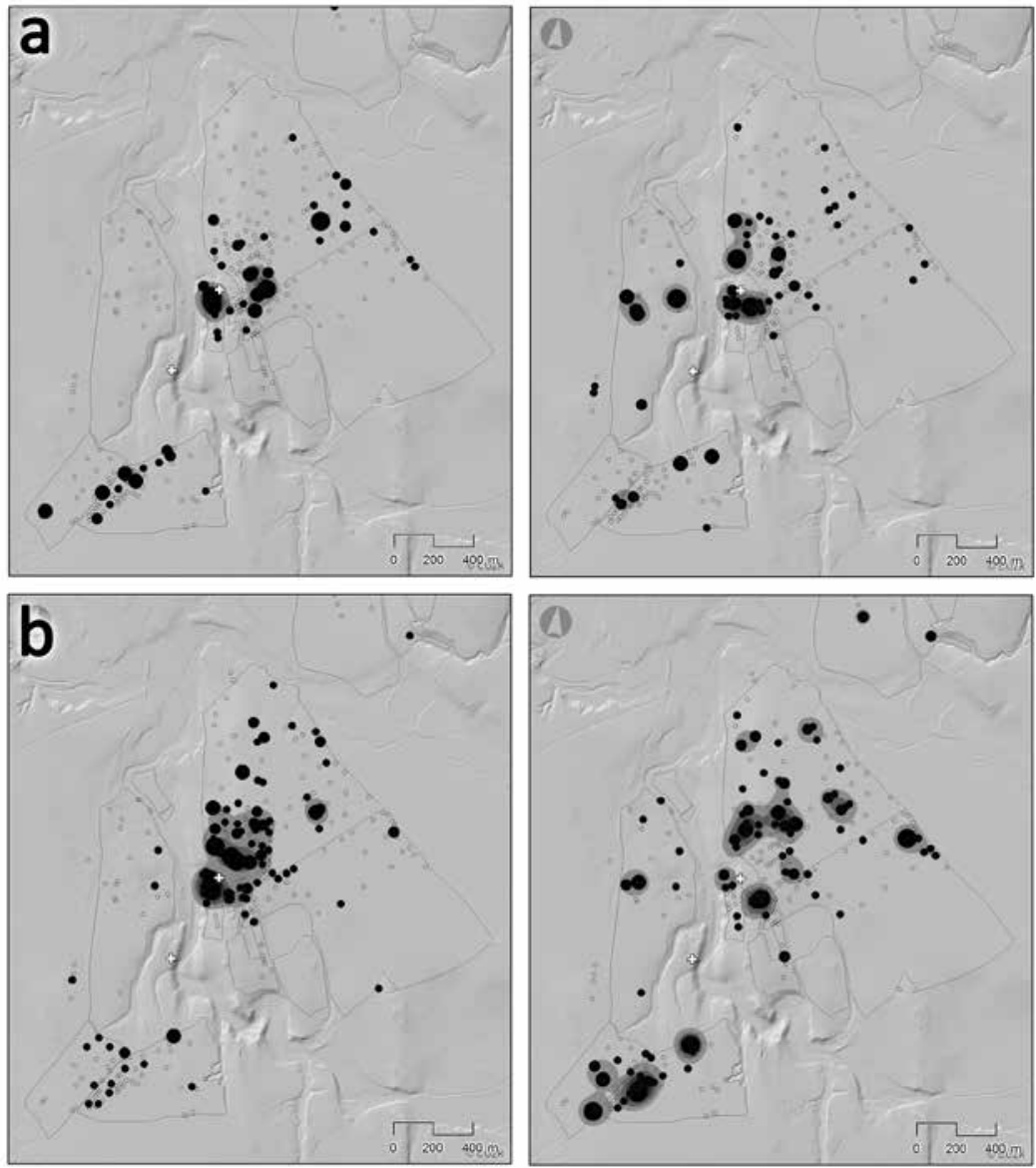

Obr. 11. Povrchové sběry v liniích, grafické vyjádření množství nalezené keramiky v keramických tř́dách Ro01 (a) a Ro02 (b) doplněné interpolací. Vlevo původní výskyt, vpravo výskyt randomizovaný (modelovaný dokonale náhodný). Zdroj podkladových dat ČúZK Praha.

Abb. 11. Liniensurveys, grafische Darstellung der gefundenen Keramikmenge in den Keramikklassen Ro01 (a) und Ro02 (b) mit vorgenommener Interpolation. Links ursprüngliches Vorkommen, rechts randomisiertes Vorkommen (modelliert, völlig zufällig). Quelle Basisdaten des Tschechischen Amtes für Landesvermessung und Kataster Prag.

komunikace směrem k městu. Starší situace se odrážela ve farní př́slušnosti Ronova ke kostelu sv. Kř́iže v Protivanech. I pro klášterní levobřeží znamenal tento posun výraznou regresi, která vyvrcholila událostmi husitských válek a války třicetileté. Za využití širšího spektra nedestruktivních archeologických metod jsme se pokusili zpřesnit závěry dřivějšího archeologického bádání. Na základě námi realizovaných povrchových sběrů se proto zdá, že osídlení celého prostoru se soustředilo především do dvou areálů. První z nich, který můžeme ztotožnit se zaniklou vsí Protivany, se nachází kolem kostela sv. Kříže ve vazbě na větvení komunikace stoupající od brodu, což dobře odpovídá písemným zmínkám o trhovém místě. Keramika se zde vyskytuje severovýchodně od kostela ve stejné intenzitě jako na poli jihozápadně od něj, kde ji nalezli už předchozí badatelé. Jiná ohniska, která bychom mohli přesvědčivě ztotožnit s místy zaniklého osídlení, na pravém břehu Doubravy v rámci zkoumané plochy neregistrujeme. Na levém břehu není situace dobře srovnatelná, velká část zázemí martinského kostela není pro sběry přístupná, nicméně relikty dokumentované v terénním reliéfu jsou patrně součástí stejného (jediného) 

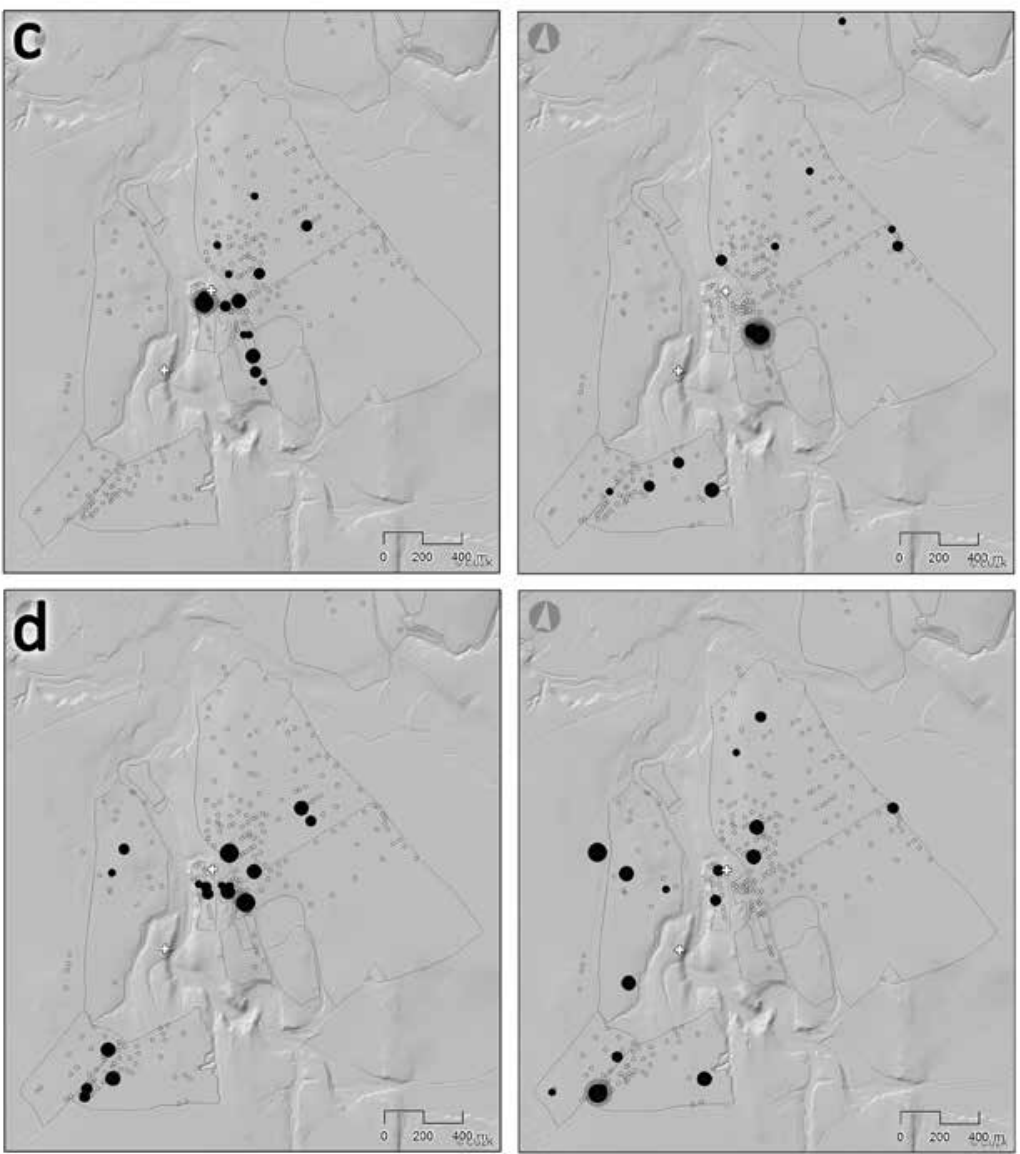

Obr. 12. Povrchové sběry v liniích, grafické vyjádření množství nalezené keramiky v keramických tř́ídách Ro03 (c) a Ro06 (d) doplněné interpolací. Vlevo původní výskyt, vpravo výskyt randomizovaný (modelovaný dokonale náhodný). Zdroj podkladových dat ČÚZK Praha.

Abb. 12. Liniensurveys, grafische Darstellung der gefundenen Keramikmenge in den Keramikklassen Ro03 (c) und Ro06 (d) mit vorgenommener Interpolation. Links ursprüngliches Vorkommen, rechts randomisiertes Vorkommen (modelliert, völlig zufällig). Quelle Basisdaten des Tschechischen Amtes für Landesvermessung und Kataster Prag.

sídelního areálu zaniklé vsi Stusyně, jehož jihozápadní cíp byl registrován povrchovými sběry. I zde patrně hrála roli vazba na komunikaci směřující k brodu. Ani v zázemí martinského kostela nebyl zjištěn další přesvědčivý výskyt středověké keramiky, který bychom považovali za jiné sídelní ohnisko. Na základě dosavadních výsledků se proto zdá, že ke každému kostelu patřil jen jeden sídelní areál. Pokud se zde uplatňoval rozptýlený model osídlení, ležely další sídelní buňky ve větši vzdálenosti od kostelů mimo zkoumanou plochu. Tuto interpretaci je však třeba brát s rezervou, protože sběry v liniích neměly homogenní pokrytí. Důkladné srovnání kvantit, a tím i přesnější klasifikaci výskytů keramiky nabízí teprve sběry ve čtvercích, které byly provedeny jen na malé části zkoumané plochy.

Tato studie je dílčím výsledkem projektu Studentské grantové soutěže Západočeské univerzity v Plzni SGS-2017-003. 

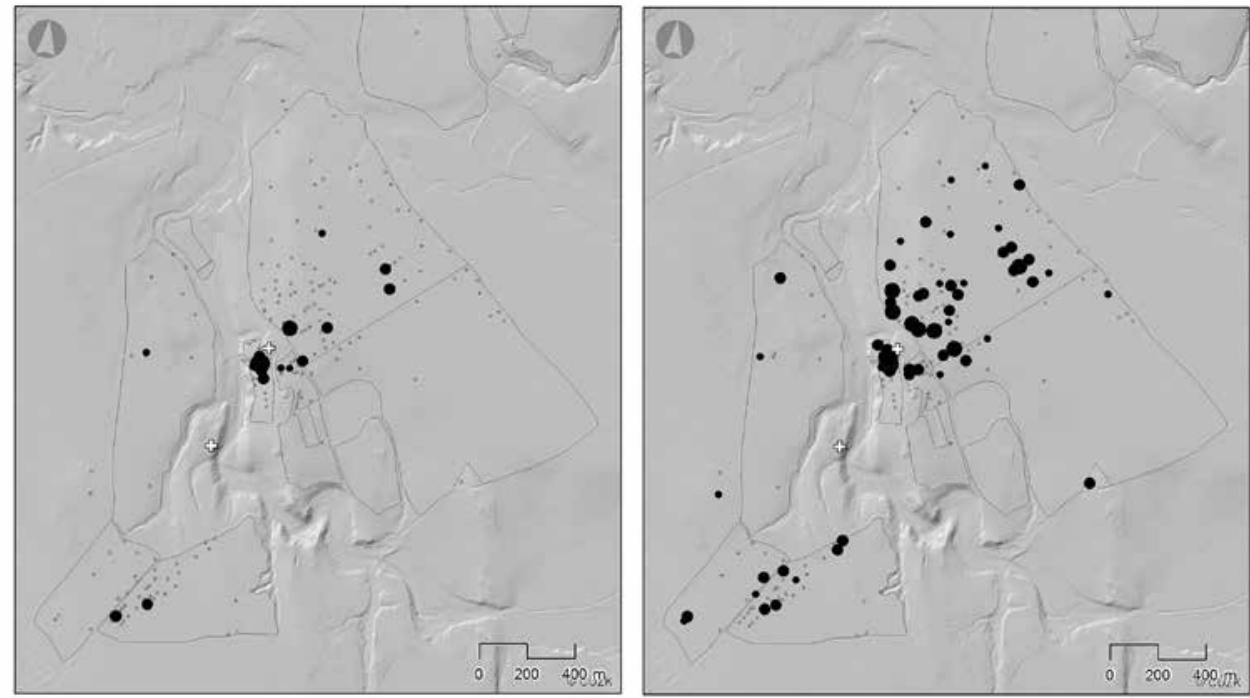

Obr. 13. Povrchové sběry v liniích, grafické vyjádření množství nalezené stř̌edověké keramiky, sloučené podle chronologie (Ro03 a Ro06, RS4, vlevo a Ro01, Ro02, Ro09, Ro12, Ro13 a Ro14, vpravo), indikující pravděpodobná místa předlokačního osídlení.

Abb. 13. Liniensurvey, grafische Darstellung der gefundenen Menge mittelalterlicher Keramik, zusammengefasst gemäß Chronologie (Ro03 und Ro06, RS4 links, und Ro01, Ro02, Ro09, Ro12, Ro13 und Ro14 rechts), indiziert wahrscheinliche Besiedelungsorte vor ihrer Erschließung (Lokation).

\section{Popis technologických keramických tříd}

\section{1 „pravěk“}

1. černá, šedočerná

2. jemně plavené těsto

3. červenohnědá, šedivá, či sendvičový efekt

4. opticky měkký, oxidačně redukční

5. pečlivě upravený, hlazený, leštěný povrch, tuhování

6. -

\section{Ro1 „šedá s kožovitým přetahem se slídou“}

1. světle béžově šedá, místy černošedá

2. písčité ostřivo (až $2 \mathrm{~mm}$ ), slída se koncentruje v povrchové části střepu

3. černošedé jádro, sendvičový efekt, velmi tenkostěnný

4. oxidační, sendvičový efekt, opticky tvrdý

5. jemný povrch, kožovitý přetah na povrchu vysoce slídnatý

6. CRF 12, 212, Ra35, Seč 5

\section{Ro2 „oxidační oranžová“}

1. světle oranžová

2. kamínky, písek ( $0,5 \mathrm{~mm})$, slída

3. světle oranžový

4. oxidační, opticky měkký

5. hladký

6. Seč 7 


\section{Ro3 „tmavě hnědošedá“}

1. tmavě hnědošedá až černošedá

2. kamínky, písek, jemně drcená slída

3. černošedý

4. redukční, opticky měkký

5. střední až hrubý

6. -

\section{Ro4 „šedá redukčni““}

1. černá, šedá, šedobéžová, bělošedá, šedobílá, kovově šedá lesklá

2. mikroskopické ostřivo, místy ojedinělý kamínek

3. světle šedá až bělobéžová a krémově bílá

4. redukční, opticky tvrdý

5. jemný, někdy leštěný vodorovně a radiálně, často kovově lesklý, vytáčení

6. CRF 17, 217, Ra4, Oheb 4, NH4, Bolešov 5, P001, Podlažice 7, Kovářov 1, Lažany 13, Hrochův Týnec 8, Seč 3

\section{Ro5 „oxidační s mikroskopickým ostřivem bez glazury“}

1. oranžová, hnědočervená, červená

2. písčité ostřivo (do $1 \mathrm{~mm}$ ), dutinky

3. oranžový, okrový, červený, místy i sendvičový efekt

4. oxidační, opticky měkký až střední

5. pečlivě upravený, vytáčení, modelační rýžky

6. 231, P008, Ra32, Strádov 16, Bolešov 6

\section{Ro6 „oxidačni““}

1. hnědooranžová

2. písek, slída velmi jemné

3. hnědooranžová

4. oxidační, opticky měkký

5. střední až hrubý

6. -

\section{Ro7}

1. bělobéžová, uvnitř částečně transparentní glazura - žlutá, nazelenalá, nahnědlá

2. jemné plavené těsto, mikroskopické ostřivo

3. bílá, bělobéžová

4. oxidační, opticky stř̌ední

5. jemný pečlivě upravený povrch, hladký, modelační rýžky

6. $312, \operatorname{Ra} 28$

\section{$\operatorname{Ros}$}

1. oranžová, hnědočervená, červená

2. písčité ostřivo (do $1 \mathrm{~mm}$ ), dutinky

3. oranžová, okrová, červená, místy i sendvičový efekt

4. oxidační, opticky měkký až střední

5. pečlivě upravený, vytáčení, modelační rýžky, slída na povrchu

6. podobná Ro5, liší se jen slídou

\section{Ro9 „světle šedé slídnaté zboží typu Zbyslavec“}

1. světle šedá

2. velmi drobné písčité a slídnaté ostřivo (1,5-2 mm) 
3. světle šedá

4. redukční, opticky měkký

5. pečlivě upravený hladký až střední, vytáčení

6. 232, Bolešov 3, Oheb 10, Podlažice 6, Ra34, Seč 2

\section{Ro10}

1. bělobéžová

2. jemné plavené těsto, mikroskopické ostřivo

3. bílá, bělobéžová

4. oxidační, opticky strední

5. jemný pečlivě upravený povrch, hladký, modelační rýžky

6. 320

\section{Ro11 „kachle No“}

1. bělobéžová, režná i glazovaná

2. jemné plavené těsto, mikroskopické ostřivo

3. bílá, bělobéžová

4. oxidační, opticky stř̌ední

5. jemný pečlivě upravený povrch, hladký, modelační rýžky

6. 317

\section{Ro12 „oxidační zboží se sendvičovým efektem a kožovitým povrchem“}

1. béžová, hnědookrová a světle hnědá

2. písčité ostřivo, kamínky $(0,5-2 \mathrm{~mm})$, jemně krupičkovité, mírně porézní

3. sendvičový efekt

4. oxidační, sendvičový efekt, opticky tvrdý

5. kožovitý, pečlivě upravený povrch

6. 219, částečně spadá i do okruhu bílé červeně malované, místy i archaičtější radélko Ra16, NH10, PodlaŽice 1 , Seč 9 , Žumberk 16

\section{Ro13 „zboží typu Sečská přehrada“}

1. hnědá, šedohnědá, černošedá

2. písčité ostřivo, hrubě drcená slída

3. hnědá a hnědošedá

4. oxidačně redukční, opticky měkký

5. hrubý, ostřivo vystupuje na povrch

6. Bolešov 1, Kovářov 4, Seč 1 , Strádov 3, Stoupec 3, TK1

\section{Ro14 „oxidační zboží s přetaženým krupičkovitým povrchem jemné na dotyk“}

1. oranžová, světle hnědá, okrová

2. jemné písčité ostřivo (okolo $0,5 \mathrm{~mm}$ ), slída velmi jemně mletá, dutiny $(0,5-1 \mathrm{~mm}$ )

3. sendvičový efekt, světlá, tmavé jádro, světlá

4. oxidační, opticky měkký až střední

5. jemný přetažený krupičkovitý povrch, jemné na dotyk

6. CRF 18, 218, Ra36, NH13, Oheb 6, Seč 6

\section{Ro15}

1. okrová, světle oranžová; uvnitř hnědočervená transparentní glazura

2. mikroskopické ostřivo, plavené těsto

3. okrová, světle oranžová

4. oxidační, opticky střední až měkký 
5. hladký, pečlivě upravený, vytáčení; částečně i oboustranně glazovaný hnědou, hnědočervenou žlutavou, žlutozelenou transparentní glazurou

6. 226

\section{Ro16 „grafitová keramika“}

1. kovově šedá, místy béžový přetah, tmavě šedá, šedohnědá, černošedá

2. zrna grafitu (2-5 mm)

3. kovově šedá, černošedá, šedočerná

4. redukční, opticky měkký

5. střední až hrubý povrch, místy šedobéžový přetah

6. 208, CRF 8, jihočeská, jihomoravská oblast, Ra 21, Podlažice 5, Kovářov 2, Lažany 11, Hrochův Týnec 10

\section{Ro17}

1. oranžová, okrová, zelená transparentní glazura, nástřepí, červenooranžový střep

2. mikroskopické ostřivo

3. oranžová, okrová, cihlově červená

4. oxidační, opticky střední

5. jemný pečlivě upravený povrch, hladký, modelační rýžky

6. de facto umělá skupina, do které spadá kukačkou a štětcem malované zboží, 307

\section{Ro18 „mužakovská kamenina“}

1. tmavě hnědá, hnědá, uvnitř světlejší až šedá

2. slinutý

3. šedá

4. oxidační (?), velmi tvrdý

5. vně hladký pečlivě upravený povrch krytý hnědou opakní glazurou, místy nalepené křemínky, vytáčení, na vnitřní straně stopy smrštění

6. 301

\section{Ro19}

1. tmavě hnědá opakní zemitá glazura (v případě zboží z Boleslawiece/Bunzlau je na vnitřní straně bílá opakní glazura)

2. částečně slinutý

3. bělobéžová, bělošedá až světle šedá

4. oxidační, opticky tvrdý

5. jemný pečlivě upravený povrch, hladký

6. 315

\section{Ro20}

1. okrová a oranžová, uvnitř částečně TG žlutá, nazelenalá, nahnědlá

2. jemné plavené těsto, mikroskopické ostřivo

3. okrová, oranžová

4. oxidační, opticky střední

5. jemný pečlivě upravený povrch, hladký, modelační rýžky

6. $311, \mathrm{Ra} 25$

\section{Ro21}

1. vně tmavě fialová burelová opakní glazura, uvnitř hnědočervená či oranžová transparentní glazura

2. jemné plavené těsto, mikroskopické ostřivo

3. oranžová, červená a okrová

4. oxidační, opticky střední

5. jemný pečlivě upravený povrch, hladký, modelační rýžky

6. $314, \mathrm{Ra} 29$ 


\section{Ro22 ,loštická“}

1. hnědá, hnědošedá

2. velmi jemný křemičitý písek (zrna $\leq 0,5 \mathrm{~mm}$ ), dutiny, póry

3. černošedé jádro, sendvičový efekt

4. oxidačně redukční výpal, opticky tvrdý až slinutý střep, vytáčení

5. charakteristický bradavičnatý povrch s kožovitým vzhledem

6. 211, CRF 11, Strádov 15, NH6

\section{Ro23 „tovární bělnina“}

1. bílá bělobéžová

2. bez makroskopických příměsí, jemně plavená kaolinická hlína

3. bílá, krémově béžová

4. oxidační, opticky měkký

5. hladký, střední stěna, oboustranná glazura

6. 308

\section{Ro24}

1. šedá, šedobéžová

2. písčité ostřivo (až $2 \mathrm{~mm}$ ), jemně mletá slída, dutiny (až $1 \mathrm{~mm}$ )

3. černé jádro, sendvičový efekt

4. redukční se sendvičovým efektem, opticky tvrdý, vytáčení (?)

5. hrubší povrch, ostřivo vystupuje na povrch, abrazí povrchu dochází k obnažování černého jádra, vlivem styku s plamenem docházelo k oprýskání, často jemná hustá šroubovice

6. anal. čáslavské zboží, Podlažice 17 , Strádov 4

\section{Ro25 „kachle VS“}

1. světle i tmavě oranžová, cihlově okrová, hnědookrová

2. kamínky $(0,5-1 \mathrm{~mm})$

3. světle i tmavě oranžová, cihlově okrová, hnědookrová

4. oxidační, opticky střední

5. hladký

6. 222, Ra11, NH1, Oheb 2, Podlažice 16

\section{Prameny a literatura}

BÍLEK, T. V., 1883: Dějiny konfiskací v Čechách po roce 1618. Část druhá. Praha.

BINTLIFF, J.-SNODGRASS, A., 1988: Off-Site Pottery Distributions: A Regional and Interregional Perspective, Current Anthropology 3/29, 503-516.

BIRNBAUMOVÁ, A.-JANSOVÂ, L., 1929: Soupis památek historických a uměleckých v politickém okresu Čáslavském. Praha.

CEJPOVÁ, M., 2008: Zbyslavec, okr. Chrudim, Výzkumy v Čechách 2005, 312.

CULEK, A., 1958: Drobné př́spěvky k dějinám města Ronova n. Doubravou, Pardubický kraj II, 47-52.

ČAPEK, L.-MALINA, O.-RYTÍŘ, L., 2013: Jenišovice (okr. Písek) - výzkum zaniklé středověké vesnice na základě prostorové distribuce keramiky, AVJČ 26, 183-206.

ČERMÁK, K., 1874-1877: Současný přehled držitelů zboží v kraji Čáslavském dle register kontribuce z r. 1622, Památky archaeologické a místopisné X, 320-330.

-1882-1884: Kde hledati jest Suchotlesky?, Památky archaeologické a místopisné XII, 238-239.

- 1885: Starožitné památky kostela sv. Kř́ǐž u Ronova, Archaeologické př́spěvky z Čáslavska III, 1-8.

- 1893: Nejstarší listiny archivu města Ronova nad Doubravou, Památky archaeologické a místopisné XVI, 819.

DANIELISOVÁ, A., 2010: Oppidum České Lhotice a jeho sídelní zázemí. Praha.

FALTYSOVÁ, H.-BÁRTA, F., edd., 2002: Chráněná území ČR. Svazek IV. Pardubicko. Praha.

FRB II: Fontes rerum bohemicarum II. (Emler, J., ed.). Praha 1874. 
FROLÍK, J., 1982: Archeologické nálezy a minulost Skutečska. Skuteč.

- 1984: Archeologické nálezy Chrudimsko (k-t). Chrudim.

- 1989: Nález raněstředověké keramiky ze Sečské přehrady na Chrudimsku, Zpravodaj Krajského muzea východních Čech XVI, č. 1, 70-77.

- 1989a: Archeologické památky Hlinecka a Chrastecka. Hlinsko.

FROLÍK, J.-MUSIL, J.-SIGL, J., sine dato: Manuál technologických skupin středověké a novověké keramiky na Chrudimsku. Rkp. ulož. na archeologickém pracovišti Regionálního muzea v Chrudimi.

FROLÍK, J.-SIGL, J., 1995: Chrudimsko v raném stř̌edověku. Hradec Králové.

- 1999: Nálezová zpráva o záchranném archeologickém výzkumu na lokalitě Chrudim - Filištínská ulice čp. 37/I-40/I. Svazek 4 - Sumarizace nálezů - čp. 37/I, sondy A, B. Nálezová zpráva čj. 819/99, ulož. v Archivu nálezových zpráv ARÚ AV ČR, Praha, v. v. i.

FROLÍK, J.-STRÁNSKÁ, P.-ŠVÉDOVÁ, J., 2018: Hrochův Týnec, počátky zdejšího kostela sv. Martina a feudálního sídla - Hrochův Týnec, the beginnings of the local Church of St. Martin and of a feudal residence, ASČ 22, 971-1004.

HORÁK, J., 2011: Prostorové analýzy dat, VŠB-TU Ostrava, HGF, Institut geoinformatiky, nestr.

CHARVÁT, P., 1982: Ř́kovice u Litomyšle a koncentrace osídlení ve středověku - The village of Ř́kovice by the town of Litomyšl and medieval concentration of settlement, AH 7, 225-228.

JEŽEK, M., 2007: Jaroměřsko v raném středověku, AR LIX, 523-570.

KLÁPŠTĚ, J., 1993: Změna - středověká transformace a její předpoklady. In: Mediaevalia Archaeologica Bohemica. Památky archeologické - Supplementum 2, 9-59. Praha.

KLÁPŠTĚ, J., 2005: Proměna českých zemí ve středověku. Praha.

KLÁPŠTĚ, J.-TOMÁŠEK, M., 2000: Nástin raně stř̌edověkého osídlení v Bylanech u Kutné Hory. In: In memoriam Jan Rulf. PA - Supplementum 13, 165-181. Praha.

KUNA, M., 2004: Povrchový sběr. In: Kuna, M. a kol., Nedestruktivní archeologie, 305-352. Praha.

KURKA, J., 1914: Archidiakonáty kouřimský, boleslavský, hradecký a diecese litomyšlská. Praha.

LÍVA, V., 1951: Prameny k dějinám třicetileté války. Regesta fondu Militare archivu ministerstva vnitra ČSR v Praze. Díl 3. Praha.

- 1953: Prameny k dějinám třicetileté války. Regesta fondu Militare archivu ministerstva vnitra ČSR v Praze. Díl 4. Praha.

LC III-IV: Libri confirmatiorum ad beneficia ecclesiastica pragensem per archidioecesim III-IV (Emler, J., ed.). Pragae 1879 .

LE V: Libri erectionum archidioecesis pragensis saeculo XIV. et XV. Tomus V (Borový, C., ed.). Pragae 1889.

MALINA, O., 2010: Transformace osídlení v prostředí GIS - zpracování dat z povrchových sběrů. In: Zborník GIS v archeológii (Blažová, E.-Gálová, L., edd.), 86-99. Nitra.

- 2011: Stabilizace sídelní sítě vrcholného středověku ve střední a západní Evropě. Nepublikovaná disertační práce, ulož. na KAR FF ZČU v Plzni.

- 2012: Samostatně stojící kostel jako doklad transformace osídlení - možnosti archeologie a GIS, Svorník 2010, 33-44.

- 2015: Hledání neviditelného. Relikty plužiny zaniklých středověkých vsí a možnosti jejich detekce a interpretace na datech LLS, ZPP 76, 513-520.

MEDUNA, P., 1992: K vnitřní struktuře raně středověkých sídlišt' - Zur inneren Struktur der frühmittelalterlichen Siedlungen, AH 17, 281-289.

MUSIL, J., 2007: Neznámá zaniklá středověká vesnice pod Sečskou přehradou (k. ú. Seč a Hoješín, okr. Chrudim), ZMHK 33, 199-219.

- 2009: An assemblage of late Middle Age and Early Modern period ceramics from Rabštejnek Castle in the cadastral territory of Smrkový Týnec in the district of Chrudim, Studies in Post-Medieval Archaeo$\log 3,45-64$.

- 2011: Nové středověké a raně novověké nálezy z Trhové Kamenice (okr. Chrudim, Pardubický kraj), Východočeský sborník historický 19, 59-104.

- 2011a: Příspěvek archeologie k dějinám Trhové Kamenice, okr. Chrudim, ASČ 15, 969-988.

- 2012: Pověst nebo realita? aneb Záchranný archeologický výzkum při odbahňování Panského rybníka ve Stolanech v roce 2011, Chrudimský vlastivědný sborník 16, 207-236.

- 2014: Soubor keramiky z velitelského stanoviště pod hradem Lichnicí (k. ú. Podhradí v Železných horách, okr. Chrudim), AVČ 5 (2013), 87-111.

- 2016: Př́íspěvek k poznání hmotné kultury hradu Strádova (k. ú. Ochoz u Nasavrk, okr. Chrudim), AVČ 8 (2014), 54-87. 
- v tisku: Zaniklá středověká vesnice pod Sečskou přehradou (k. ú. Seč a k. ú. Hoješín, o. Chrudim) aneb Ústupky roku 1315?, Chrudimský vlastivědný sborník.

MUSIL, J.-NETOLICKÝ, P., 2012: Zaniklá středověká a raně novověká ves Bolešov v k. ú. Spačice, okres Chrudim, Pardubický kraj, Východočeský sborník historický 22, 73-114.

- 2013: Studium dynamiky středověkých sídelních struktur v tzv. bojanovském újezdu (Železné hory, okres Chrudim), REA - Živá archeologie 15, 32-37.

- 2014: Současný stav a perspektivy výzkumu antropogenních pozůstatků sídelních, výrobních a těžebních areálů v prostoru Železných hor, AVČ 5 (2013), 227-239.

- 2014a: Pozůstatky rýžování zlata v tzv. bojanovském újezdu (okres Chrudim) - Goldwäschereirelikte im sog. Bojanov-Sprengel (Bezirk Chrudim), AH 39, 637-655.

- 2014b: Tvrziště Stoupec a jeho hospodářské zázemí. Výsledky povrchového průzkumu na k. ú. Březinka u Hoštalovic (okr. Chrudim), AVČ 5 (2013), 148-180.

- 2014c: Dokumentace reliktů středověké těžby kovů v Železných horách, REA - Živá archeologie 16, 32-38.

- 2015: Výsledky povrchového průzkumu Železných hor v roce 2014, Výzkumy v Čechách 2014. Zprávy ČAS - Supplément 97, 52.

- 2015a: Rýžování zlata na Chrudimsku, REA - Živá archeologie 17, 60.

- 2015b: Dokumentace reliktů předhradí hradu Strádova (okres Chrudim) - Dokumentation der Relikte der Vorburg von der Burgruine Strádov (Bezirk Chrudim), AH 40, 457-473

- 2016: Nové archeologické nálezy z tzv. bojanovského újezdu (Železné hory, okres Chrudim), Praehistorica XXXIII, č. 1-2, 275-290.

- 2016a: Mezi vesnicí a vrchnostenským sídlem. Dvory na středověkém Chrudimsku - Zwischen Dorf und Herrschaftssitz. Mittelalterliche Höfe in der Region Chrudim, AH 41, 211-238.

- 2017: Př́íspěvek k poznání polních opevňovacích objektů z roku 1968 na Chrudimsku - Feldbefestigungsobjekte aus dem Jahr 1968 in der Region Chrudim, AH 42, 579-593.

- 2018: Povrchový průzkum sídlištního a hospodářského komplexu tvrze Suchotlesky (k. ú. Ronov nad Doubravou) - Oberflächenuntersuchung des Siedlungs- und Wirtschaftskomplexes der Feste Suchotlesky (Katastergebiet Ronov nad Doubravou), AH 43, 423-435.

NOHEJLOVÁ-PRÁTOVÁ, E., 1957: Nálezy mincí v Čechách, na Moravě a ve Slezsku III. Praha.

NOVÁK, D.-VAŘEKA, P., 2016: A Late-Medieval manor farm in Rovný (Rokycany District, Pilsen Region), AH 41, 211-227.

PAVLŮ, I., 1982: K počátkům Čáslavě. I. Katalog - Archeologické nálezy při městských hradbách, Praehistorica X - Varia archaeologica 3, 75-160.

PEHAL, Z., 2001: Sídliště ze 13. století na katastru obce Frýdnava (okr. Havl. Brod), Sborník Havlíčkobrodské společnosti pro povznesení regionálně historického povědomí 1, 5-9.

- 2001a: Sídliště ze 13. století na katastru obce Stupárovice (okr. Havl. Brod), Sborník Havlíčkobrodské společnosti pro povznesení regionálně historického povědomí 1, 96-100.

- 2003: Keramika 13. století od kostela svatého Kř́iže nedaleko Ronova nad Doubravou (okr. Chrudim), Chrudimský vlastivědný sborník 7, 3-17.

- 2006: Zaniklá středověká vesnice na katastru Stupárovic, okres Havlíčkův Brod, ZMHK 32, 124-139.

PROFOUS, A., 1951: Místní jména v Čechách. Jejich vznik, původní význam a změny. Díl III. M-Ř. Praha.

PROFOUS, A.-SVOBODA, J., 1957: Místní jména v Čechách. Jejich vznik, původní význam a změny. Díl IV. S-Ž. Praha.

RBM IV: Regesta diplomatica nec non epistolaria Bohemiae et Moraviae IV (Emler, J., ed.). Praha 1892.

ROUBÍK, F., 1959: Soupis a mapa zaniklých osad v Čechách. Praha.

ROUS, P.-VESELÝ, E., 1981: Archeologické nálezy na území okresu Havlíčkův Brod v letech 1979-1980, Zpravodaj Krajského muzea východních Čech v Hradci Králové VIII, 16-20.

SEDLÁČEK, A., 1900: Hrady, zámky a tvrze království Českého. Díl XII. Praha.

- 1909: Místopisný slovník historický království Českého. Praha.

SMETÁNKA, Z., 1977: Nálezová zpráva - povrchový průzkum ZSO Stusyně, k. o. Ronov nad Doubravou, ulož. v Archivu nálezových zpráv ARÚ AV ČR, Praha, v. v. i., TX197702257.

- 1987: Hledání zmizelého věku. Praha.

SMETÁNKA, Z.-KLÁPŠTĚ, J., 1981: Geodeticko-topografický průzkum zaniklých středověkých vsí na Černokostelecku, PA LXXII, 416-445.

SMETÁNKA, Z.-ŠKKABRADA, J., 1975: Nové poznatky o raně středověké architektuře na Čáslavsku, Umění XXIII, 262-266.

- 1977: K počátkům městečka Ronova nad Doubravou. In: Středověká archeologie a studium počátků měst (Richter, M., ed.), 105-112. Praha. 
SOMER, T.-ŠRÁMEK, J., 2010: Historie benediktinského opatství sv. Petra a Pavla ve Vilémově (11601541). Praha.

SVOBODA, J.-ŠMILAUER, V., 1960: Místní jména v Čechách. Jejich vznik, původní význam a změny. Díl V. Dodatky k dílu Antonína Profouse. Praha.

ŠKABRADA, J.-SMETÁNKA, Z., 1974: K metodice povrchového průzkumu raně středověké vesnice, PP 5, 297-306.

ŠIMÁK, J. V., 1938: Středověká kolonisace v zemích Českých. České dějiny I/5. Praha.

ŠTĚPÁN, L.-ŠULC, I., 2013: Chrudimsko. Mlýny a další zařízení na vodní pohon. Chrudim.

TOMÁŠEK, M., 1995: Archeologický výzkum hradebního pásma v Čáslavi v roce 1993, AR XLVII, 444-454.

VAŘEKA, P., 1998: Proměny keramické produkce vrcholného a pozdního středověku v Čechách - The erratic character of ceramic production in High and Later Middle Age in Bohemia, AR L, 123-137.

- 2008: Zaniklý dvůr Nevězeň. In: Vařeka, P. a kol., Archeologie zaniklých středověkých vesnic na Rokycansku II, 117-126. Plzeň.

- 2014: Zaniklá stř̌edověká a časně novověká ves Rovný na Zbirožsku (okr. Rokycany), AZČ 7, 131-143.

- 2016: Zaniklá středověká a časně novověká vesnice Bukov na Zbirožsku (okr. Rokycany), AZČ 10, $156-167$.

VAŘEKA, P. a kol., 2006: Archeologie zaniklých středověkých vesnic na Rokycansku I - Archaeology of Deserted Medieval Villages in the Rokycany-Region (West Bohemia) I. Plzeň.

ZAHRADNÍKOVÁ, M.-ŠREINOVÁ, E., 1999: Soupis poddaných podle víry z roku 1651. Čáslavsko 2. Praha.

ZÁPOTOCKÝ, M., 1978: Středověká keramika severočeského Polabí. Morfologie a relativní chronologie, PA LXIX, 171-238.

\section{Zusammenfassung}

\section{Veränderungen der Siedlungsstruktur im Umland von Ronov an der Doubrava}

Das Umland der Stadt Ronov an der Doubrava gehörte zusammen mit der majestätischen Burg Lichnice zum ehemaligen historischen Zentrum der Region Čáslav. Heute gehört es verwaltungsmäßig zum im Landkreis Pardubice liegenden Bezirk Chrudim. Die relativ offene Landschaft des Elbgebietes wellt sich dort leicht und geht nach und nach in das Massiv des Eisengebirges über, das im Mittelalter eine natürliche Barriere bildete. Eine wichtige Verbindungslinie in dem Gebiet stellte der Fluss Doubrava dar, an dem der sog. Libitzer Weg entlang verlief. In der Umgebung der Stadt finden sich zwei einzeln stehende romanische Kirchen, bei denen sich an einer ehemaligen Furt über die Doubrava die mittelalterlichen Dorfwüstungen Protivany/Protivenice und Stusyně befanden. Beide Dörfer existierten vor der Entstehung von Ronov an der Doubrava, das Ulrich von Lichtenburg im Jahr 1307 gründen ließ. Gerade bei der Siedlung Protivany mit der Heiliz-Kreuz-Kirche nimmt man die Existenz eines ehemaligen Marktfleckens an. Der Markt wurde dann zusammen mit dem Zentrum der Pfarreiverwaltung in das neugegründete Städtchen verlegt. Beide Siedlungen verloren nach und nach an Bedeutung, aber einen endgültigen Punkt hinter ihre Existenz haben erst die Ereignisse des Dreißigjährigen Krieges gemacht. Den Anfängen der Stadt Ronov an der Doubrava und ihrer Beziehung zu den Wüstungen Protivany und Stusyně wurde in der Vergangenheit eine beträchtliche Aufmerksamkeit gewidment, besonders was die Umwandlung des mittelalterlichen Siedlungsnetzes anbelangt. Dank analytischen Oberflächensurveys war es möglich, bestimmte technologische Keramikgruppen zu unterscheiden, die wir aufgrund des hohen Maßes ihrer Konzentration als Relikte von wüsten Siedlungslagen oder als Beleg für die intensive Nutzung bestimmter Orte ansehen noch bevor die Besiedelung an Stellen der heutigen Stadt Ronov verlegt wurden.

Im südwestlichen Teil des Katasters der Stadt Ronov an der Doubrava befinden sich auch die ein wenig übergangenen Relikte der mittelalterlichen Dorfwüstung Suchotlesky. Der Komplex besteht aus der eigentlichen Dorfwüstung, einem Herrschaftssitz (Festung) mit angeschlossenem wirtschaftlichen Hinterland in Form eines Hofes und einer Mühle mit mindestens drei 
Teichen. Das Dorf ist besonders aus der älteren Regionalliteratur sowie von Übersichts- und Verzeichnisarbeiten her bekannt.

Die vorliegende Studie ist ein Teilergebnis des Studentischen Förderwettbewerbprojektes der Westböhmischen Universität in Pilsen SGS-2017-003.

Mgr. Ondřej Malina, Ph.D., Národní památkový ústav, územní odborné pracoviště v Lokti, Kostelní 81/25, 35733 Loket, Česká republika, malina.ondrej@npu.cz,omalin@seznam.cz

PhDr. Jan Musil, Regionální muzeum v Chrudimi, Široká 86, 53701 Chrudim; Katedra archeologie Fakulty filozofické Západočeské univerzity v Plzni, Sedláčkova 15, 30614 Plzeň, Česká republika, musil@muzeumcr.cz

Mgr. Petr Netolický, Ph.D., Katedra archeologie Fakulty filozofické Západočeské univerzity v Plzni, Sedláčkova 15, 30614 Plzeň, Česká republika,netolicky.petr@seznam.cz 
